\title{
Titania Nanosheet Generates Peroxynitrite-Dependent $S$-Nitrosylation and Enhances p53 Function in Lung Cancer Cells
}

\author{
Rapeepun Soonnarong ${ }^{1,2}$, Sucharat Tungsukruthai ${ }^{3}$, Bodee Nutho ${ }^{4}$, Thanyada Rungrotmongkol ${ }^{5,6}$, \\ Chanida Vinayanuwattikun ${ }^{7}$, Tosapol Maluangnont ${ }^{8(1)}$ and Pithi Chanvorachote ${ }^{2,9, *}$ (i)
}

Citation: Soonnarong, R.; Tungsukruthai, S.; Nutho, B.; Rungrotmongkol, T.;

Vinayanuwattikun, C.; Maluangnont, T.; Chanvorachote, P. Titania

Nanosheet Generates PeroxynitriteDependent S-Nitrosylation and Enhances p53 Function in Lung Cancer Cells. Pharmaceutics 2021, 13, 1233. https://doi.org/10.3390/ pharmaceutics 13081233

Academic Editor: Santosh Aryal

Received: 8 July 2021

Accepted: 3 August 2021

Published: 10 August 2021

Publisher's Note: MDPI stays neutral with regard to jurisdictional claims in published maps and institutional affiliations.

Copyright: (c) 2021 by the authors Licensee MDPI, Basel, Switzerland. This article is an open access article distributed under the terms and conditions of the Creative Commons Attribution (CC BY) license (https:// creativecommons.org/licenses/by/ $4.0 /)$.
1 Interdisciplinary Program of Pharmacology Graduate School, Chulalongkorn University, Bangkok 10330, Thailand; rapeepun.s@student.chula.ac.th

2 Cell-Based Drug and Health Products Development Research Unit, Faculty of Pharmaceutical Sciences, Chulalongkorn University, Bangkok 10330, Thailand

3 Department of Pharmacology, Faculty of Science, Prince of Songkla University, Hat Yai 90110, Songkhla, Thailand; sucharat.tungsukruthai@gmail.com

4 Department of Pharmacology, Faculty of Science, Mahidol University, Bangkok 10400, Thailand; bodee.nut@mahidol.ac.th

5 Biocatalyst and Environmental Biotechnology Reseach Unit, Department of Biochemistry, Faculty of Science, Chulalongkorn University, Bangkok 10330, Thailand; thanyada.r@chula.ac.th

6 Program in Bioinformatics and Computational Biology, Graduate School, Chulalongkorn University, Bangkok 10330, Thailand

7 Department of Medicine, Division of Medical Oncology, Chulalongkorn University, Pathumwan, Bangkok 10330, Thailand; chanida.Vi@chula.ac.th

8 King Mongkut's Institute of Technology Ladkrabang, College of Materials Innovation and Technology, Bangkok 10520, Thailand; tosapol.ma@kmitl.ac.th

9 Department of Pharmacology and Physiology, Faculty of Pharmaceutical Sciences, Bangkok 10330, Thailand

* Correspondence: pithi_chan@yahoo.com or pithi.c@chula.ac.th; Tel.: +66-22-188344

\begin{abstract}
Metal nanomaterials can enhance the efficacy of current cancer therapies. Here, we show that $\mathrm{Ti}_{0.8} \mathrm{O}_{2}$ nanosheets cause cytotoxicity in several lung cancer cells but not in normal cells. The nanosheet-treated cells showed certain apoptosis characteristics. Protein analysis further indicated the activation of the p53-dependent death mechanism. Transmission electron microscopy (TEM) and scanning electron microscopy (SEM) analyses revealed the cellular uptake of the nanosheets and the induction of cell morphological change. The nanosheets also exhibited a substantial apoptosis effect on drug-resistant metastatic primary lung cancer cells, and it was found that the potency of the nanosheets was dramatically higher than standard drugs. $\mathrm{Ti}_{0.8} \mathrm{O}_{2}$ nanosheets induce apoptosis through a molecular mechanism involving peroxynitrite $\left(\mathrm{ONOO}^{-}\right)$generation. As peroxynitrite is known to be a potent inducer of $S$-nitrosylation, we further found that the nanosheets mediated the $S$-nitrosylation of p53 at C182, resulting in higher protein-protein complex stability, and this was likely to induce the surrounding residues, located in the interface region, to bind more strongly to each other. Molecular dynamics analysis revealed that $S$-nitrosylation stabilized the $\mathrm{p} 53$ dimer with a $\Delta G_{\text {bind }}^{\text {residue }}$ of $<-1.5 \mathrm{kcal} / \mathrm{mol}$. These results provide novel insight on the apoptosis induction effect of the nanosheets via a molecular mechanism involving S-nitrosylation of the p53 protein, emphasizing the mechanism of action of nanomaterials for cancer therapy.
\end{abstract}

Keywords: apoptosis; nanosheets; lung cancer; p53; S-nitrosylation; peroxynitrite; molecular dynamics

\section{Introduction}

Lung cancer is one of the most common cancers worldwide, with the highest mortality rate. Although a number of crucial components in the fight against lung cancer have been elucidated, including small-molecule tyrosine kinase inhibitors and immunotherapy, which have led to unprecedented survival benefits in selected patients, the overall cure 
and survival rates for non-small cell lung cancer (NSCLC) remain low [1]. Therefore, new research discovering new drugs and therapies is essential to improve clinical outcomes. Tumor suppressor p53 is an essential regulatory molecule that is implicated in cell cycle arrest and plays a mediator role in apoptosis in response to stress [2]. A key attribute of the p53 response is p53 stabilization, which results in a rapid increase in p53 steadystate levels. Considerable evidence has indicated that p53 stabilization largely depends on post-translational events that disengage p53 from its proteasomal degradation [3]. In all cases, this includes a series of post-translational modifications, some of which are known to impact the interaction between p53 and the mouse double minute 2 (MDM2) protein, representing the major mechanism for controlling p53 stability [4]. The activation of p53 results in an increase in BH3-only proteins, promoting Bax/Bak oligomerization. The induction of pro-apoptotic signaling leads to the formation of mitochondrial pores, the release of cytochrome c into the cytosol, the activation of caspases, and finally cell apoptosis [5]. However, the upregulation of pro-survival proteins, including mammalian target of rapamycin (mTOR) and anti-apoptotic proteins of the Bcl-2 family, has been shown to play roles in apoptosis resistance [6].

p53, an important tumor suppressor protein, has been intensively investigated as its functions are critical for cancers. The functions of the p53 protein are tightly associated with its protein conformation. The active conformation of this protein is the tetrameric form via an interaction of the tetramerization domain (TD) on the p53 protein. Studies have pointed out that the tetramerization of p53 is critical for DNA binding and post-translational modification as well as for p53 stability [7]. Cysteine thiol groups on the p53 molecule have been highlighted as sensitive sites for protein modification, and it was shown that the DNA-binding affinity could be altered by thiol blocking agents [8]. Certain cysteine residue amino acid replacements inhibit the binding of p53 to DNA [9]. In addition, several lines of evidence have demonstrated that the oxidative modification of cysteine residues within p53 can also influence the protein's activity and stability [10-12].

Nitric oxide (NO) is a key intercellular messenger synthesized from l-arginine in a reaction catalyzed by $\mathrm{NO}$ synthases (NOS). NO is recognized as an important signaling molecule for controlling practically all critical cellular functions, and it is also a strong mediator of cellular damage [13]. Interestingly, NO has been shown to regulate the expression of many genes, and this effect is exerted, in part, via S-nitrosylation [14]. S-nitrosylation of a certain side of transcription factors can modulate transcription factor activation, protein stability, and localization, as in the case of p53 and hypoxia-inducible factor- $1 \alpha$ (HIF-1 $\alpha$ ) [15] In addition, $\mathrm{NO}$ can react with superoxide $\left(\mathrm{O}_{2}^{-}\right)$to form the much more powerful oxidant peroxynitrite $\left(\mathrm{ONOO}^{-}\right)$, which is a key component that determines the contrasting roles of NO in physiology and pathology [16]. Many of the biological effects ascribed with NO are actually related to the intermediate peroxynitrite. Even though peroxynitrite is a powerful oxidant, it reacts at a moderately slow rate with most biological molecules and is able to reach cell membranes, in part, through anion channels [17]. This makes the biological and pathological insinuations of peroxynitrite much more interesting because it can have more delicate and specific actions on cells.

Nanotechnology is a research field that has wide implications in the fields of chemistry, engineering, biology, and medicine. Nanotechnology has several applications in cancer biology, especially in the development of novel treatments [18]. Nanosheets are a developing class of nanomaterial that are highly anisotropic and flexible [19]. $\mathrm{Ti}_{0.8} \mathrm{O}_{2}$ nanosheets are the two-dimensionality (2D) analog of $\mathrm{TiO}_{2}$ with potential anti-cancer stem cell activity [20]. However, to the best of our knowledge, the nanotoxicity and mechanism of $\mathrm{Ti}_{0.8} \mathrm{O}_{2}$ nanosheets for specific site-targeting strategies in NSCLC have not yet been investigated. Consequently, this study aims to investigate the effects of $\mathrm{Ti}_{0.8} \mathrm{O}_{2}$ nanosheets on the cytotoxicity of human non-small cell lung cancer (NSCLC) cells and to identify the molecular mechanisms behind the toxicity of these cells, which we reveal to be related to ROS generation-mediated apoptosis via the mitochondrial pathway. This study could be valuable in the development of nanomaterials for anti-cancer approaches. 


\section{Materials and Methods}

\section{1. $\mathrm{Ti}_{0.8} \mathrm{O}_{2}$ Nanosheet Synthesis and Characterization}

The $\mathrm{Ti}_{0.8} \mathrm{O}_{2}$ nanosheets were prepared as reported previously. Briefly, the potassium zinc titanate $\mathrm{K}_{0.8} \mathrm{Zn}_{0.4} \mathrm{Ti}_{1.6} \mathrm{O}_{4}$ was first synthesized by heating the stoichiometric mixture of $\mathrm{K}_{2} \mathrm{CO}_{3}, \mathrm{ZnO}$, and $\mathrm{TiO}_{2}$ at $900{ }^{\circ} \mathrm{C}$ for $20 \mathrm{~h}$. Then, the solid was soaked in $1 \mathrm{M} \mathrm{HCl} \mathrm{overnight}$ (solid-to-solution ratio of $1 \mathrm{~g}$ to $100 \mathrm{~mL}$ ) for a total of 3 cycles, with fresh acid replaced in between. The product is $\mathrm{H}_{1.6} \mathrm{Ti}_{1.6} \mathrm{O}_{4} \cdot 0.8 \mathrm{H}_{2} \mathrm{O}$, where $0.8 \mathrm{H}^{+}$is first exchanged for $0.8 \mathrm{~K}^{+}$, another $0.8 \mathrm{H}^{+}$for the leached [21] $0.4 \mathrm{Zn}^{2+}$, with water inclusion. Finally, 0.4 of the protonic form was mechanically shaken at $180 \mathrm{rpm}$ for 14 days with diluted tetrabutylammonium hydroxide (TBAOH) solution (1 M, Sigma-Aldrich, St. Louis, MO, USA). The solid-tosolution ratio was fixed at 0.4 g-to- $100 \mathrm{~mL}$ and the $\mathrm{TBA}^{+} / \mathrm{H}^{+}$ratio at 1 . The white colloid of $\mathrm{Ti}_{0.8} \mathrm{O}_{2}$ nanosheets was then obtained.

The absorption characteristics of the nanosheets colloid were measured using a $\mathrm{T}^{+}$ UV/VIS spectrometer (PG Instruments, Lutterworth, UK). The "size" of the nanosheets (i.e., the hydrodynamic radius, as determined by dynamic light scattering) and the zeta potential were measured using a Beckman Coulter Delsa Nano (Beckman Coulter Inc., Fullerton, CA, USA) instrument. The nanosheets were also imaged using a JEOL JEM 2010 (Beckman Coulter Inc., Fullerton, CA, USA) transmission electron microscope. Other results can be found in more detail elsewhere.

\subsection{Cell Culture and Reagents}

H23, H292, H460, and A549 lung cancer cells were obtained from the American Type Culture Collection (Manassas, VA, USA). A primary human dermal papilla cell line (primary DP1) was purchased from Celprogen (Benelux, The Netherlands). A human keratinocyte cell line (HaCaT) was purchased from Cell Lines Service (Heidelberg, Germany). Immortalized dermal papilla cells (DP) and human primary hair follicle dermal papilla cells (primary DP2) were purchased from Applied Biological Materials Inc (Richmond, BC, British Columbia). H460, H292, and H23 cells were cultured in RPMI 1640 medium (Gibco, Grand Island, NY, USA), whereas A549, HaCaT, DP, and primary DP1 and DP2 cells were cultivated in DMEM medium (Gibco, Grand Island, NY, USA). The medium was supplemented with $10 \%$ fetal bovine serum (FBS), 100 units $/ \mathrm{mL}$ penicillin/streptomycin, and $2 \mathrm{mM}$ L-glutamine (Gibco, Waltham, MD, USA). The cells were incubated in a $5 \% \mathrm{CO}_{2}$ environment at $37^{\circ} \mathrm{C}$. Phosphate buffer saline (PBS) and trypsin-EDTA were purchased from GIBCO (Grand Island, NY, USA). Dimethyl sulfoxide, MTT, Hoechst 33342 staining, bovine serum albumin (BSA) dihydroethidium (DHE), and propidium iodide (PI) were purchased from Sigma Chemical, Inc. (St. Louis, MO, USA). An apoptosis kit (FITC) was purchased from ImmunoTools (Friesoythe, Germany). $2^{\prime}, 7^{\prime}$-Dichlorofluorescein (DCF) and $3^{\prime}$-p-(hydroxyphenyl) fluorescein (HPF) were purchased from Invitrogen (Waltham, MD, USA). Mn(III)tetrakis (4-benzoic acid) porphyrin (MnTBAP) was purchased from Merck (Calbiochem, La Jolla, CA, USA). Antibodies for p-p53 (Ser15), p53, Bcl-2, Mcl-1, Bax, caspase3, and $\beta$-actin, as well as peroxidase-conjugated secondary antibodies, were obtained from Cell Signaling Technology, Inc. (Danvers, MA, USA). Pierce S-nitrosylation Western blot kits were obtained from Thermo Fisher Scientific (Calbiochem, La Jolla, CA, USA).

\subsection{Patient-Derived Primary Lung Cancer Cell Line Preparation from Malignant Pleural Effusion}

The patient-derived lung cancer cells were prepared from pleural effusion of recurrent or advanced stage non-small cell lung cancer patients at the King Chulalongkorn Memorial Hospital. The Ethics Committee of the Faculty of Medicine, Chulalongkorn University, Bangkok, Thailand (IRB 581 365/62) approved the protocol. Informed consent from all contributors was obtained. Pleural effusion (approximately $1000 \mathrm{~mL}$ ) was collected through thoracentesis. The samples were centrifuged at $300 \times g$ for $10 \mathrm{~min}$. The cells were cultured in RPMI medium with 10\% FBS, 2 mM L-glutamine, and 100 units/mL each of penicillin and streptomycin. 


\subsection{Cytotoxicity Assay}

Cells were seeded onto 96-well plates at the density of $1 \times 10^{4}$ cells/well and were allowed to incubate overnight. Then, cells were treated with various concentrations $(0-100 \mu \mathrm{g} / \mathrm{mL})$ of $\mathrm{Ti}_{0.8} \mathrm{O}_{2}$ nanosheets for $24 \mathrm{~h}$ at $37^{\circ} \mathrm{C}$ and analyzed for cell viability using a 3-(4,5-dimethylthiazol-2-yl)-2,5-diphenyltetrazolium bromide (MTT) assay. The MTT product was measured at $570 \mathrm{~nm}$ using a microplate reader. Cell viability was calculated by dividing the absorbance of the treated cells by that of the control cells and represented in percentage. All analyses were performed in 3 independent replicate cell cultures.

\subsection{Nuclear Staining Assay}

To determine apoptotic and necrotic cell death, $\mathrm{H} 460$ and A549 cells were seeded onto 96-well plates at the density of $1 \times 10^{4}$ cells/well, incubated overnight, and then treated with $\mathrm{Ti}_{0.8} \mathrm{O}_{2}$ nanosheets at various concentrations $(0-10 \mu \mathrm{g} / \mathrm{mL})$ for $24 \mathrm{~h}$ at $37^{\circ} \mathrm{C}$. After that, the cells were incubated with Hoechst $33342(10 \mu \mathrm{g} / \mathrm{mL})$ and propidium iodide (PI) $(5 \mu \mathrm{g} / \mathrm{mL})$ for $30 \mathrm{~min}$ at $37^{\circ} \mathrm{C}$ in the dark. These cells were imaged under a fluorescence microscope (Nikon ECLIPSE Ts2, Tokyo, Japan).

\subsection{Cell Apoptosis Analysis}

The stages of apoptosis and necrosis cells were determined with annexin V-FITC apoptosis kits (ImmunoTools, Germany). H460 and A549 cells were seeded in 24-well plates at a density of $1 \times 10^{5}$ cells $/ \mathrm{mL}$ and treated with $\mathrm{Ti}_{0.8} \mathrm{O}_{2}$ nanosheets at various concentrations $(0-10 \mu \mathrm{g} / \mathrm{mL})$ for $24 \mathrm{~h}$. Then, the cells were detached and suspended in $100 \mu \mathrm{L}$ of $1 \times$ binding buffer and incubated in $5 \mu \mathrm{L}$ of annexin V-FITC and $1 \mu \mathrm{L}$ of PI for $15 \mathrm{~min}$ at room temperature in the dark. Next, the cells were analyzed by guava easyCyte ${ }^{\mathrm{TM}}$ flow cytometry systems.

\subsection{Scanning Electron Microscopy (SEM) Morphological Analysis}

Cells were fixed in $2.5 \%$ glutaraldehyde in $0.1 \mathrm{M}$ phosphate buffer ( $\mathrm{pH} 7.2)$ for $2 \mathrm{~h}$. Next, the cells were dehydrated with a graded series of ethanol $(30 \%, 50 \%, 70 \%$, and $95 \%$ for $5 \mathrm{~min} /$ each and 100\% 3 times, $5 \mathrm{~min} /$ time), dried, mounted, and coated with gold (sputter coater, Balzers model SCD 040, Wetzlar, Germany). Finally, the cells were observed under SEM (JEOL, model JSM6400, Tokyo, Japan).

\subsection{Transmission Electron Microscopy (TEM) for Cellular Uptake Analysis}

Cells were seeded at the density of $1 \times 10^{6}$ cells $/ \mathrm{mL}$ and treated with $\mathrm{Ti}_{0.8} \mathrm{O}_{2}$ nanosheets at $10 \mu \mathrm{g} / \mathrm{mL}$ for $24 \mathrm{~h}$. The cells were collected, washed with PBS, and fixed in $2 \%$ glutaraldehyde, post-fixed in $1 \%$ osmium tetroxide, dehydrated in alcohol, and embedded. Thin sections of the resin-embedded cells were cut and subjected to a JEM-1400 (Jeol Ltd., Tokyo, Japan) transmission electron microscope (TEM).

\subsection{Western Blot Analysis}

After treatment, the cells were lysed, as previously described. Equal amounts of protein from each sample were subjected to SDS-PAGE for separation and transferred to nitrocellulose or PVDF membranes (Bio-Rad, Hercules, CA, USA). The blots were blocked for $1 \mathrm{~h}$. with $5 \%$ non-fat dry milk [20] and, after that, incubated with specific primary antibodies against p-p53 (Ser15), p53, Bcl-2, Mcl-1, Bax, caspase 3, and $\beta$-actin at $4{ }^{\circ} \mathrm{C}$ overnight. Then, the blots were washed in TBST and incubated with horseradish peroxidase (HRP)-conjugated secondary antibodies for $2 \mathrm{~h}$ at room temperature. Finally, protein bands were detected using an enhanced chemiluminescence substrate (Supersignal West Pico; Pierce, Rockford, IL, USA) and exposed to film. 


\subsection{ROS, Superoxide Anion, and Hydroxyl Radical Detection by Flow Cytometry}

A549 and H460 were seeded in 24-well plates and cultured for $12 \mathrm{~h}$. DCFHDA, DHE, and HPF were added, and the cells were incubated for $30 \mathrm{~min}$ in the dark. Cells were treated with $\mathrm{Ti}_{0.8} \mathrm{O}_{2}$ nanosheets for $3 \mathrm{~h}$, washed, and resuspended in PBS. DCF fluorescence was quantified using guava easyCyte ${ }^{\mathrm{TM}}$ flow cytometry systems.

\subsection{NO Detection by DAF-FM DA Assay}

After detachment, the cells were collected and incubated with $10 \mu \mathrm{M}$ DAF-FM DA for $30 \mathrm{~min}$ at $37^{\circ} \mathrm{C}$. The cells were then washed, resuspended in phosphate-buffered saline, and analyzed for fluorescence intensity using guava easyCyte ${ }^{\mathrm{TM}}$ flow cytometry systems. These cells were imaged under a fluorescence microscope (Nikon ECLIPSE Ts2).

\subsection{Immunofluorescence}

Cells were seeded onto 96-well plates at the density of $1 \times 10^{5}$ cells/well. The cells were treated with a nanosheet and fixed with $4 \%(w / v)$ paraformaldehyde for $30 \mathrm{~min}$. The cells were permeabilized with $0.1 \%(v / v)$ Triton-X for $20 \mathrm{~min}$, incubated with $3 \%(w / v)$ BSA for $30 \mathrm{~min}$, and washed and incubated with a p53 or p-p53 antibody overnight at $4{ }^{\circ} \mathrm{C}$. The cells were washed and incubated with Alexa Flour 488 conjugated secondary antibodies for $1 \mathrm{~h}$ at room temperature. The cells were washed with PBS, co-stained with $10 \mu \mathrm{g} / \mathrm{mL}$ Hoechst 33342, and visualized under a fluorescence microscope (Nikon ECLIPSE Ts2).

\subsection{Cycloheximide (CHX) Chasing Assay}

Cells were seeded and treated with $10 \mu \mathrm{g} / \mathrm{mL}$ of $\mathrm{Ti}_{0.8} \mathrm{O}_{2}$ nanosheets with or without $50 \mu \mathrm{g} / \mathrm{mL}$ CHX for $0,15,30,45,60$, and $90 \mathrm{~min}$. The cells were lysed with RIPA lysis buffer containing the protease inhibitor cocktail (Roche Diagnostics, Indianapolis, IN, USA). Western blot analysis was performed for detecting p53 protein levels. Protein bands were analyzed using ImageJ software (version 1.52, National Institutes of Health, Bethesda, MD, USA), and the Mcl-1 protein half-life was calculated.

\subsection{Immunoprecipitation Assay}

Cells were treated with $\mathrm{Ti}_{0.8} \mathrm{O}_{2}$ nanosheets for $1 \mathrm{~h}$. Immunoprecipitation was performed using Dynabeads ${ }^{\mathrm{TM}}$ Protein $\mathrm{G}$ immunoprecipitation kits from Thermo Fisher Scientific Inc (Waltham, MA, USA). Magnetic beads were prepared and incubated with the p53 antibody for $20 \mathrm{~min}$. A bead-Ab complex was mixed with cell lysate and incubated at $4{ }^{\circ} \mathrm{C}$ overnight. The bead-Ab-Ag complex was washed three times, separated on a magnet between each wash, and the supernatant was removed. Elution buffer was added. The supernatant was then subjected to Western blot analysis.

\subsection{S-Nitrosylated Protein Detection}

Cells were lysed and centrifuged at 10,000 $\times g$ for $10 \mathrm{~min}$. To each sample, $2 \mu \mathrm{L}$ of $1 \mathrm{M}$ MMTS was added, and the samples were incubated for $30 \mathrm{~min}$ at room temperature to block free cysteine thiols. Then, the protein was precipitated by adding pre-chilled $\left(-20^{\circ} \mathrm{C}\right)$ acetone and freezing at $-20^{\circ} \mathrm{C}$ to remove MMTS for at least $1 \mathrm{~h}$. Samples were centrifuged at $10,000 \times \mathrm{g}$ for $10 \mathrm{~min}$ at $4{ }^{\circ} \mathrm{C}$. Pellets were resuspended in $100 \mu \mathrm{L}$ of HENS buffer, $1 \mu \mathrm{L}$ of the labeling reagent, and $2 \mu \mathrm{L}$ of $1 \mathrm{M}$ sodium ascorbate for $1-2 \mathrm{~h}$ at room temperature. Finally, labeled-protein SDS-PAGE and Western blotting analysis were used to detect $S$-nitrosylation p53 proteins.

\subsection{Computational Method}

The X-ray structure of the tetrameric p53 core domain was taken from the Protein Data Bank (PDB ID: 3KMD) [22]. The H++ web server [23] was used to assign the protonation state of all ionizable groups of amino acids at $\mathrm{pH}$ 7.4. The modeled protein was then submitted to all-atom molecular dynamics (MD) simulations using the AMBER16 software package according to standard procedures [24-26], as summarized below. In brief, the 
starting structure of the p53 protein was firstly energy-minimized using the steepest descent (500 steps) and a conjugated gradient (1500 steps) based on the ff14SB AMBER force field [27] to reduce unfavorable contacts. After that, a 100-ns MD simulation with the NPT ensemble at $310 \mathrm{~K}$ and $1 \mathrm{~atm}$ was carried out by the PMEMD module of AMBER16. The SHAKE algorithm [28] was applied to restrain the covalent bond involved in hydrogen atoms, allowing a simulation time step of $2 \mathrm{fs}$. The particle mesh Ewald [29] summation method was used to treat the long-range electrostatic interactions, whereas a nonbonded cutoff distance was set to $10 \AA$. The MD trajectories in the production phase were collected every 10 ps and analyzed in terms of intermolecular hydrogen bonding interaction using the CPPTRAJ module [30] of AMBER 16. To determine the essential residues associated with protein-protein binding at the interface of the four monomers and the effect of $S$-nitrosylation on the cysteine (Cys) residue towards protein stability, the per-residue decomposition free energy $\left(\Delta G_{\text {bind }}^{\text {residue }}\right)$ method, based on the molecular mechanics/PoissonBoltzmann surface area (MM/PBSA), was performed using the MMPBSA.py module [31] implemented in AMBER16.

\subsection{Statistical Analysis}

Data from three independent experiments are presented as mean \pm standard error of mean (SEM). Multiple comparisons for statistically significant differences between multiple groups were performed using analysis of variance (ANOVA), followed by Turkey's post hoc test. $p$-values $<0.05$ were considered statistically significant.

\section{Results}

\subsection{Synthesis and Characterization of the $\mathrm{Ti}_{0.8} \mathrm{O}_{2}$ Nanosheets}

The preparation of the $\mathrm{Ti}_{0.8} \mathrm{O}_{2}$ nanosheets from lepidocrocite-type $\mathrm{K}_{0.8} \mathrm{Zn}_{0.4} \mathrm{Ti}_{1.6} \mathrm{O}_{4}$ is shown schematically in Figure $1 \mathrm{~A}$. Here, the $\mathrm{K}^{+}$ion ( 0.8 per the formula unit) alternately stacks with the negatively-charged sheets of edge-shared (Ti, $\mathrm{Zn}) \mathrm{O}_{6}$ octahedra (i.e., the $\mathrm{Zn}_{0.4} \mathrm{Ti}_{1.6} \mathrm{O}_{4}{ }^{0.8-}$ sheet with $\sim 1 \mathrm{~nm}$ thickness). Reacting the solid with $1 \mathrm{M} \mathrm{HCl}$ led to a quantitative replacement of $\mathrm{K}^{+}$with $\mathrm{H}_{3} \mathrm{O}^{+}$and almost complete $\mathrm{Zn}$ leaching. The subsequent reaction of the solid with the bulky $\mathrm{TBA}^{+}$ions resulted in the infinite separation of stacks of sheets into individual nanosheets.

As shown in Figure 1B, the obtained colloidal suspension was white with a blue tint. It absorbed light at $\lambda \max =261 \mathrm{~nm}$, which is consistent with previous reports. A clear Tyndall effect could be observed, where laser illumination was scattered throughout, suggesting the presence of nanosheets. Dynamic light scattering provided the size estimation of the $\mathrm{Ti}_{0.8} \mathrm{O}_{2}$ nanosheets as $\sim 268 \mathrm{~nm}$ (see Figure 1C). The zeta potential of $-30 \mathrm{mV}$ agreed well with their negatively charged nature. Figure 1D is a representative TEM image, showing several uniform-contrast, flat objects (i.e., nanosheets) with lateral dimensions of up to $\sim 200 \mathrm{~nm}$. Altogether, the different characterization techniques confirmed the successful preparation of negatively charged $\mathrm{Ti}_{0.8} \mathrm{O}_{2}{ }^{0.8-}$ nanosheets (or simply $\mathrm{Ti}_{0.8} \mathrm{O}_{2}$ nanosheets) in contrast to typical $\mathrm{TiO}_{2}$, which is charge-neutral. Detail characterizations can be found elsewhere [20].

\subsection{Cytotoxicity of the $\mathrm{Ti}_{0.8} \mathrm{O}_{2}$ Nanosheets on Human Lung Cancer Cells and Normal Cells}

Cells were treated with various concentrations of $\mathrm{Ti}_{0.8} \mathrm{O}_{2}$ nanosheets $(0-100 \mu \mathrm{g} / \mathrm{mL})$ and analyzed by MTT assay. The results revealed the statistically significant cytotoxic effects of the $\mathrm{Ti}_{0.8} \mathrm{O}_{2}$ nanosheets occurred at concentrations of $10-100 \mu \mathrm{g} / \mathrm{mL}$ in A549, $\mathrm{H} 460$, and $\mathrm{H} 23$ cells and at $20-100 \mu \mathrm{g} / \mathrm{mL}$ in $\mathrm{H} 292$ cells. In the primary dermal papilla cells from different sources (DP1 and DP2), cytotoxic effects of the $\mathrm{Ti}_{0.8} \mathrm{O}_{2}$ nanosheets were found at $50 \mu \mathrm{g} / \mathrm{mL}$. Moreover, at the concentration of $30 \mu \mathrm{g} / \mathrm{mL}$, the $\mathrm{Ti}_{0.8} \mathrm{O}_{2}$ nanosheets showed statistically significant cytotoxic effects on DP and HaCat cells (Figure 2A-H). Characteristic apoptosis cells were identified using a nuclear staining assay. The results showed that the $\mathrm{Ti}_{0.8} \mathrm{O}_{2}$ nanosheets mediated apoptosis in lung cancer cells at concentrations of $1-10 \mu \mathrm{g} / \mathrm{mL}$, with a small percentage of necrotic cells (Figure 2I-L). Flow 
cytometry analysis based on annexin V/PI detection also confirmed that $10 \mu \mathrm{g} / \mathrm{mL}$ of $\mathrm{Ti}_{0.8} \mathrm{O}_{2}$ nanosheets induced dramatic apoptosis in A549 and $\mathrm{H} 460$ cells compared with untreated cells (Figure 2M,N).
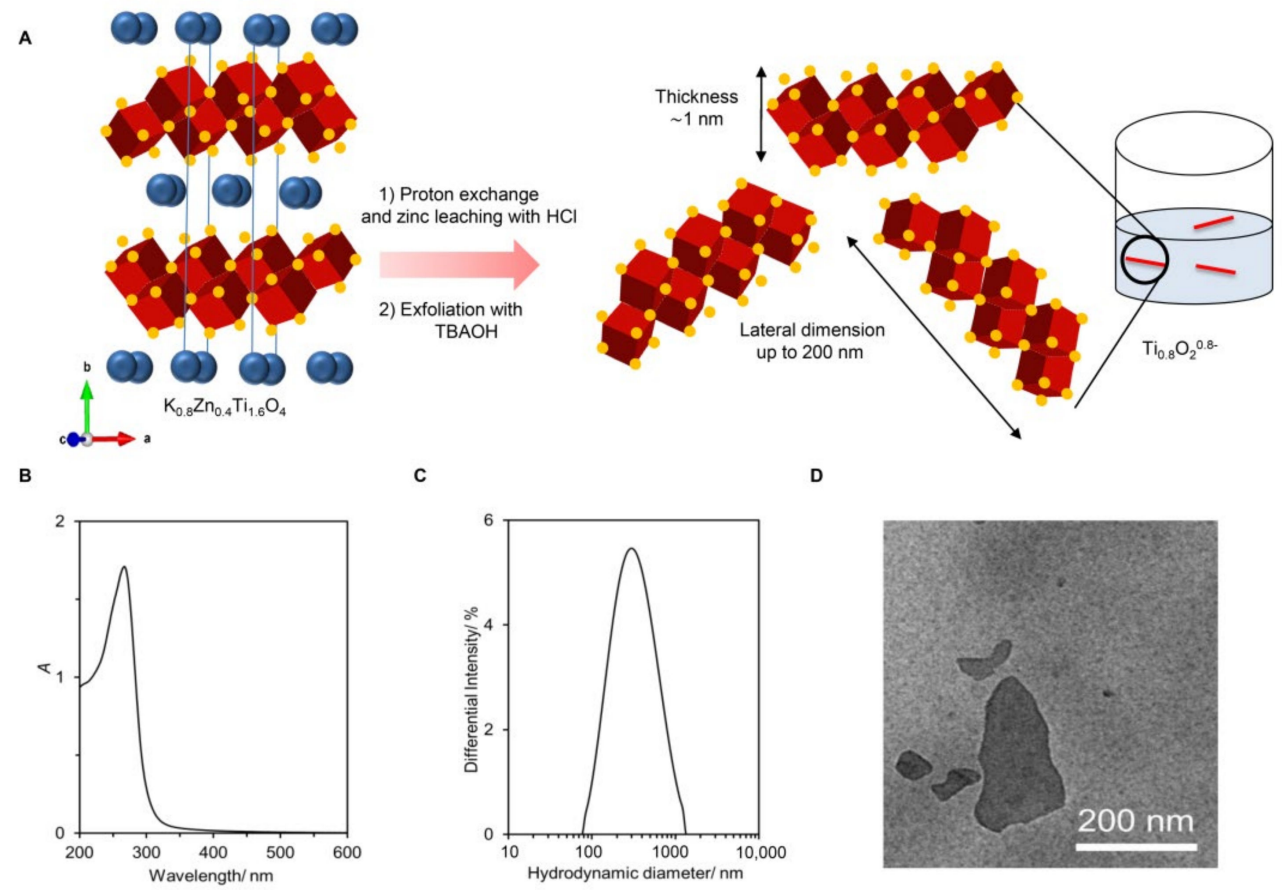

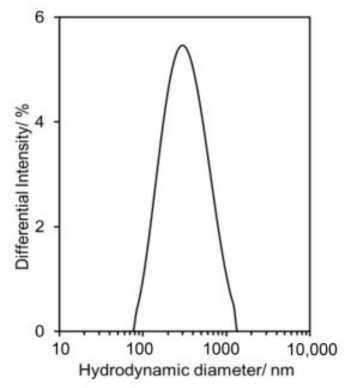

D

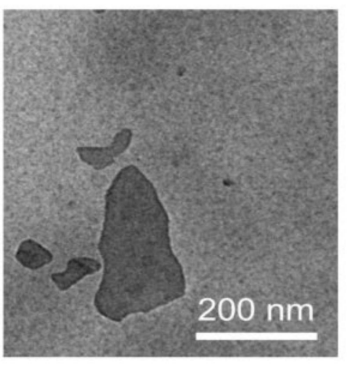

Figure 1. Synthesis and characterization of the $\mathrm{Ti}_{0.8} \mathrm{O}_{2}$ nanosheets. (A) The schematic diagram of $\mathrm{Ti}_{0.8} \mathrm{O}_{2}$ nanosheet preparation. The crystal structure of $\mathrm{K}_{0.8} \mathrm{Zn}_{0.4} \mathrm{Ti}_{1.6} \mathrm{O}_{4}$ shows $\mathrm{K}^{+}$ions (green) sandwiched between the double edge-shared $\mathrm{O}$ atoms in red and Ti atoms at the center in blue; (B) UVvis absorption spectrum and photograph of the nanosheets without and with the laser light shining through; (C) size of the nanosheets; (D) representative TEM image of the deposited nanosheets.

\subsection{Uptake of the $\mathrm{Ti}_{0.8} \mathrm{O}_{2}$ Nanosheets by Cancer Cells}

Under SEM morphological analysis, it was seen that for $\mathrm{H} 460$ cells, the morphology of the cancer cells gradually changed when treated with $\mathrm{Ti}_{0.8} \mathrm{O}_{2}$ nanosheets at concentrations of $1-10 \mu \mathrm{g} / \mathrm{mL}$ (Figure 3A). Moreover, TEM analysis showed that $\mathrm{Ti}_{0.8} \mathrm{O}_{2}$ nanosheets at $10 \mu \mathrm{g} / \mathrm{mL}$ could appropriately pass into the H460 cells (Figure 3B).

\section{4. $\mathrm{Ti}_{0.8} \mathrm{O}_{2}$ Nanosheets Modulate Apoptosis-Related Proteins in $\mathrm{H} 460$ and A549 Cells}

In order to investigate the mechanism of $\mathrm{Ti}_{0.8} \mathrm{O}_{2}$ nanosheet-induced apoptosis, the apoptotic-related proteins were determined by Western blot analysis. A549 and H460 cells were treated with $0-10 \mu \mathrm{g} / \mathrm{mL} \mathrm{Ti}_{0.8} \mathrm{O}_{2}$ nanosheets, and then the pro-and anti-apoptotic proteins related to mitochondria-mediated apoptosis were evaluated. The results showed that the $\mathrm{Ti}_{0.8} \mathrm{O}_{2}$ nanosheets increased the pro-apoptotic protein Bax, whereas the antiapoptotic proteins Mcl-1 and Bcl-2 were downregulated in the cells treated with the $\mathrm{Ti}_{0.8} \mathrm{O}_{2}$ nanosheets. In addition, pro-caspase 3 decreased in a concentration-dependent manner. Moreover, $\mathrm{Ti}_{0.8} \mathrm{O}_{2}$ nanosheets caused a significant increase in both p-p53 (Ser15) and total p53 protein levels in a dose-dependent manner (Figure $3 \mathrm{C}-\mathrm{F}$ ). These findings suggest that p53 may play a role in $\mathrm{Ti}_{0.8} \mathrm{O}_{2}$ nanosheet-induced apoptosis of NSCLC cells. Taken together, it can be concluded that the $\mathrm{Ti}_{0.8} \mathrm{O}_{2}$ nanosheets mediated the apoptosis of lung cancer cells by increasing pro-apoptotic proteins, which led to cell death by the mitochondriadependent pathway. 

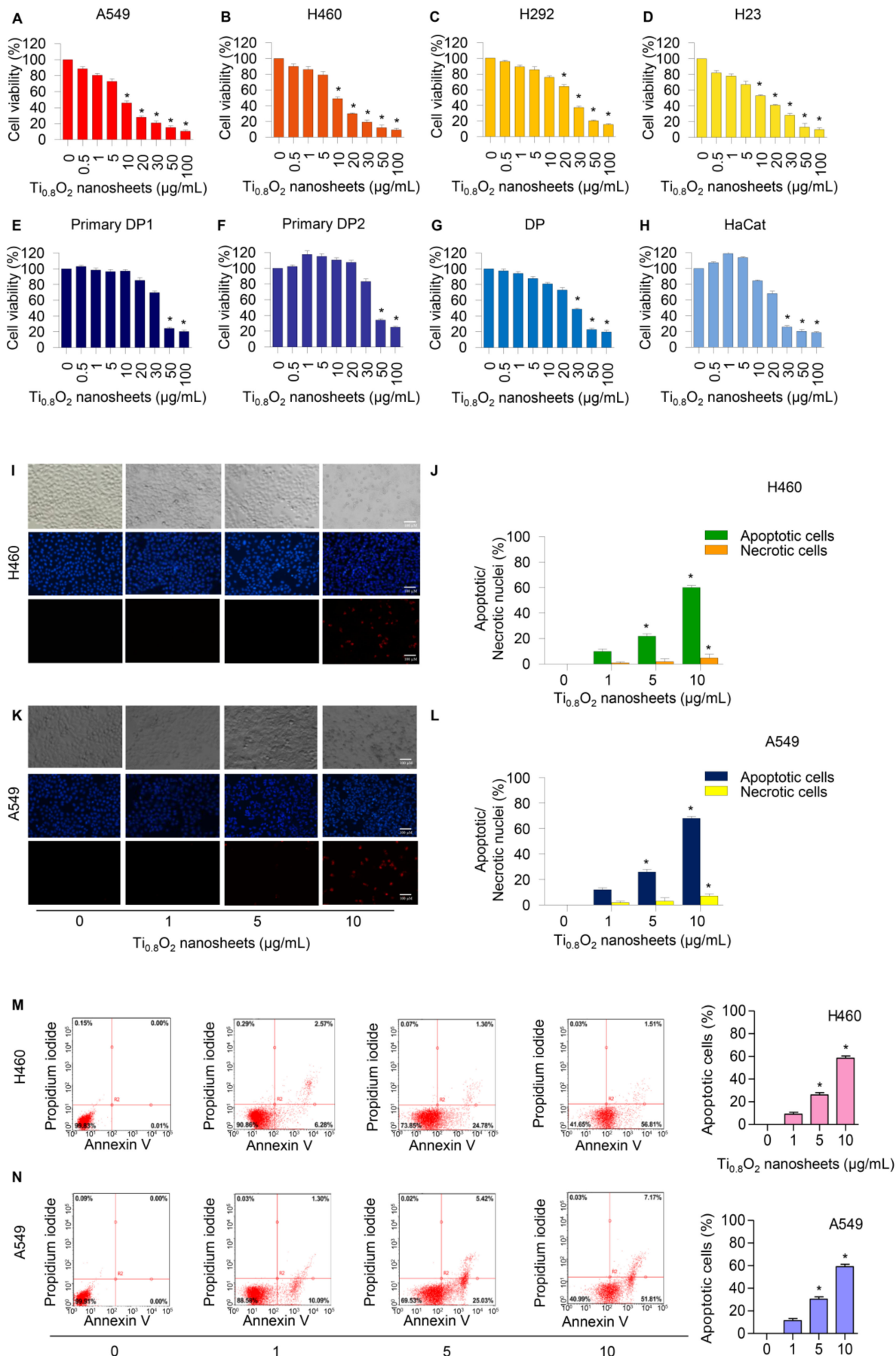

Figure 2. Cytotoxicity of $\mathrm{Ti}_{0.8} \mathrm{O}_{2}$ nanosheets on human lung cancer cells and normal cells. $\mathrm{Ti}_{0.8} \mathrm{O}_{2}$ nanosheets reduced cell viability and induced apoptosis in lung cancer cells. (A-H) Effect of $\mathrm{Ti}_{0.8} \mathrm{O}_{2}$ nanosheets on cell viability of lung cancer cells (A549, H460, H292, and H23 cells) and normal cells (dermal papilla (DP), primary DP1, primary DP2, and HaCaT keratinocyte cells) for $24 \mathrm{~h}$ using MTT assays; (I-L) morphology of apoptotic nuclei stained with Hoechst 33342 dye and propidium iodide in cells treated with $\mathrm{Ti}_{0.8} \mathrm{O}_{2}$ nanosheets, determined by visualization using fluorescence microscopy and calculated percentages of nuclear fragmented and PI-positive cells; $(\mathbf{M}, \mathbf{N})$ apoptotic and necrotic cells were determined using annexin V-FITC/PI staining with flow cytometry; data are shown as the mean $\pm \operatorname{SEM}(n=3) .{ }^{*} p<0.05$ versus non-treated control. 
${ }^{\text {A }}{ }_{460}$

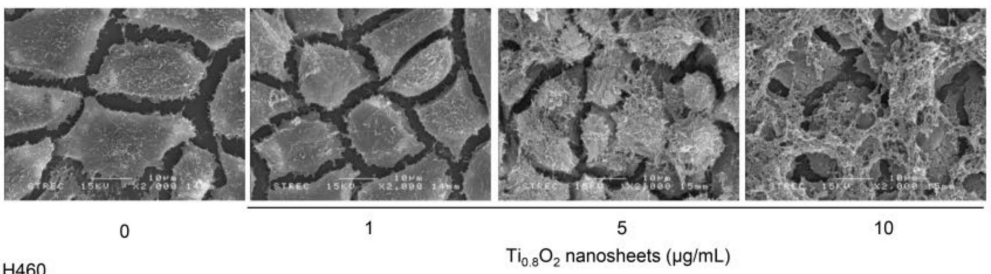

H460
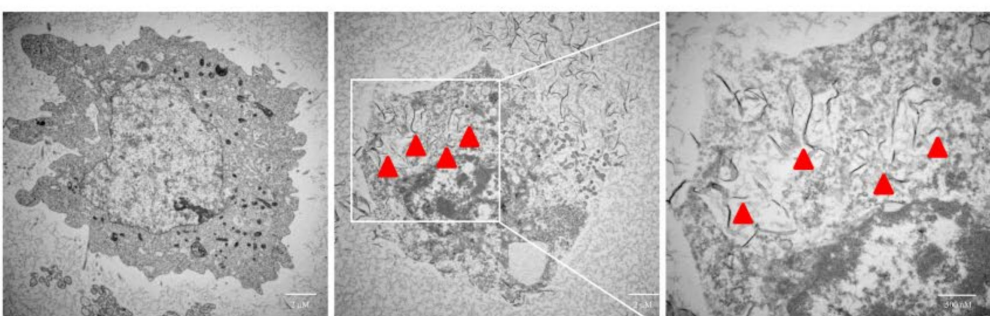

Primary DP
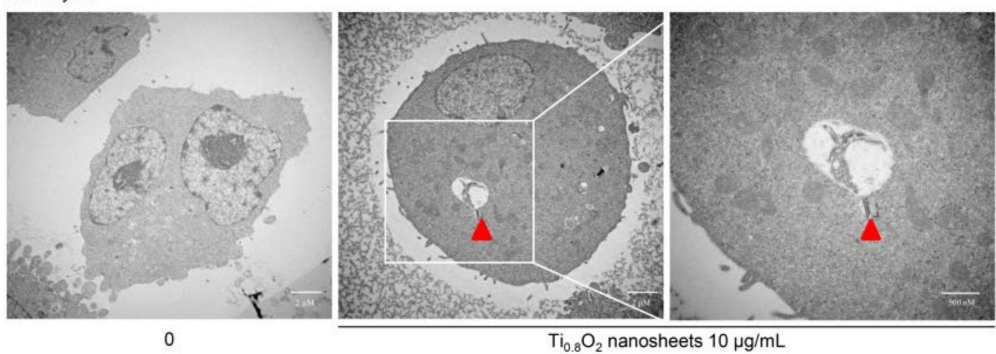

c

$$
\mathrm{H} 460
$$

$\mathrm{kDa}$
53
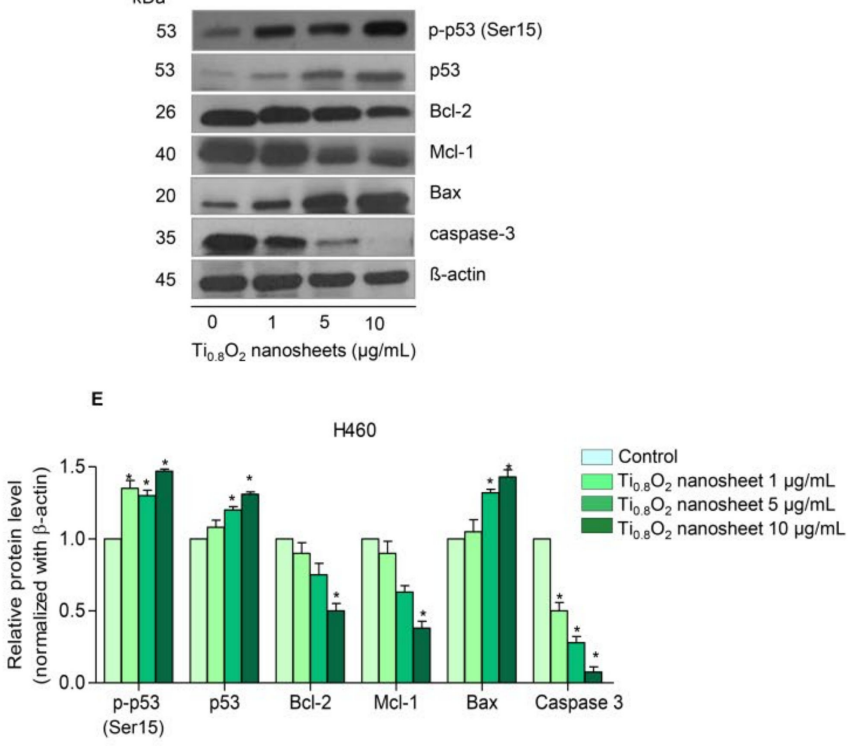

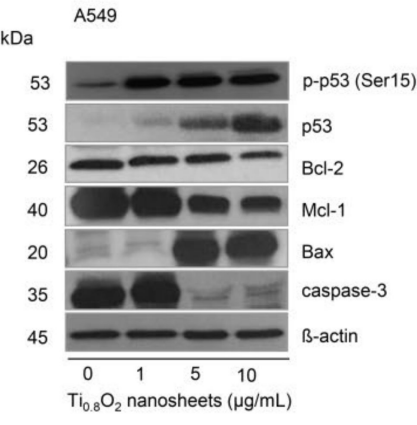

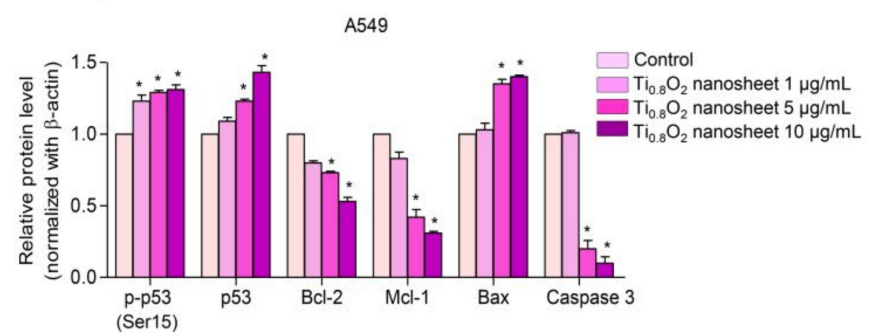

Figure 3. Morphology and characterization of cells when treated with $\mathrm{Ti}_{0.8} \mathrm{O}_{2}$ nanosheets. (A) Morphology of $\mathrm{H} 460$ cells determined by scanning electron microscopy (SEM); (B) cellular uptake of $\mathrm{Ti}_{0.8} \mathrm{O}_{2}$ nanosheets in $\mathrm{H} 460$ and primary DP cells at $24 \mathrm{~h}$, determined by transmission electron microscopy (TEM); (C,D) effect of $\operatorname{Ti}_{0.8} \mathrm{O}_{2}$ nanosheets on apoptosis-related proteins measured by Western blot analysis. Blots were reprobed with $\beta$-actin to confirm the equal loading of samples; $(\mathbf{E}, \mathbf{F})$ relative protein levels, calculated by densitometry. Data are shown as the mean $\pm \operatorname{SEM}(n=3) . * p<0.05$ versus non-treated control.

\subsection{Cytotoxicity and Apoptotic Effects of $\mathrm{Ti}_{0.8} \mathrm{O}_{2}$ Nanosheets on Advanced Lung Cancer Cells from Patients}

To assess the potential pharmacological activities of synthetic $\mathrm{Ti}_{0.8} \mathrm{O}_{2}$ nanosheet compounds in advanced lung cancer cells, treatment with current standard therapeutic agents was also performed for comparison. Two groups of cell lines were used for the investiga- 
tions: Panel A, an advanced non-small cell lung cancer cell line from patients with malignant pleural effusion who had never been treated by chemotherapy, targeted therapy, or immunotherapy, and Panel B, an advanced non-small cell lung cancer cell line from patients with malignant pleural effusion who had been treated with standard platinum-doublet chemoRx with or without targeted therapy or a checkpoint inhibitor and second-line chemoRx. In total, six primary lung cancer cells were treated with the same concentrations of $\mathrm{Ti}_{0.8} \mathrm{O}_{2}$ nanosheets, cisplatin, and etoposide $(0-100 \mu \mathrm{g} / \mathrm{mL})$ for $24 \mathrm{~h}$ and subjected to cell viability analysis by MTT assay. The $\mathrm{Ti}_{0.8} \mathrm{O}_{2}$ nanosheets could be considered nontoxic at doses lower than $1 \mu \mathrm{g} / \mathrm{mL}$, while a concentration of more than $10 \mu \mathrm{g} / \mathrm{mL}$ caused a significant decrease in the cell viability of the cells (Figure 4A-F). In contrast, the standard drugs showed slightly decreased cell viability from 0.5 to $100 \mu \mathrm{g} / \mathrm{mL}$, while doses of more than $20 \mu \mathrm{g} / \mathrm{mL}$ cisplatin and etoposide were considered toxic. Data analysis showed that the $\mathrm{IC}_{50}$ of the $\mathrm{Ti}_{0.8} \mathrm{O}_{2}$ nanosheets was lower than $10 \mu \mathrm{g} / \mathrm{mL}$ at $24 \mathrm{~h}$, which was significantly lower than for cisplatin and etoposide (Figure $4 \mathrm{G}$ ). The results showed that the $\mathrm{Ti}_{0.8} \mathrm{O}_{2}$ nanosheets reduced cell viability in a concentration-dependent manner compared with the untreated controls (Figure $4 \mathrm{~A}-\mathrm{F}$ ). To confirm the effect of the $\mathrm{Ti}_{0.8} \mathrm{O}_{2}$ nanosheets on advanced lung cancer cells from patients, a nuclear staining assay using Hoechst 33342 and propidium iodide was performed and the results analyzed. After treatment with the compounds at $10 \mu \mathrm{g} / \mathrm{mL}$ of $\mathrm{Ti}_{0.8} \mathrm{O}_{2}$ nanosheets, apoptotic cells were observed by the presence of nuclear condensation morphology in the representative cell line (Figure $4 \mathrm{H}-\mathrm{M}$ ). It was found that the potency of the nanosheets was dramatically higher than that of cisplatin and etoposide.

\subsection{Effect of $\mathrm{Ti}_{0.8} \mathrm{O}_{2}$ Nanosheets on Intracellular ROS Induction in A549 and $\mathrm{H} 460$ Cells}

ROS has been considered an important mediator of the initiation and execution of apoptosis and is related to the anti-cancer effect of several drugs [32]. We next investigated whether intracellular ROS generation was implicated in the anti-cancer effects of the $\operatorname{Ti}_{0.8} \mathrm{O}_{2}$ nanosheets. The intracellular ROS level was evaluated using the fluorescent probe $\mathrm{DCFH}-$ DA. The results showed that treatment with $\mathrm{Ti}_{0.8} \mathrm{O}_{2}$ nanosheets increased intracellular ROS generation (Figure 5A-D). In order to investigate the protective effect of $\mathrm{N}$-acetylcysteine (NAC) or glutathione (GSH) as a potent antioxidant on $\mathrm{Ti}_{0.8} \mathrm{O}_{2}$ nanosheet-induced cytotoxicity mediated through ROS generation, the $\mathrm{H} 460$ and A549 cell lines were pretreated with NAC or GSH for $1 \mathrm{~h}$ previous to treatment with the $\mathrm{Ti}_{0.8} \mathrm{O}_{2}$ nanosheets. We detected a decrease in the ROS level in all the cell lines treated with NAC and GSH (Figure 5A-D), but the cell viability of the cancer cells could not be reversed by the pretreatment with NAC or GSH (Figure 5E,F). These results suggest that the $\mathrm{Ti}_{0.8} \mathrm{O}_{2}$ nanosheets induce cytotoxicity in cancer cell lines but do not do this via the generation of ROS. Next, we investigated the specific ROS products using a DHE (dihydroethidium) fluorescent probe for the detection of ROS generation and, specifically, the detection of superoxide anions. The results showed that the $\mathrm{Ti}_{0.8} \mathrm{O}_{2}$ nanosheets had a significant effect on the superoxide anions in $\mathrm{H} 460$ cells when they were treated with $\mathrm{Ti}_{0.8} \mathrm{O}_{2}$ nanosheets in a concentration-dependent manner (Figure 5G,I), while the $\mathrm{Ti}_{0.8} \mathrm{O}_{2}$ nanosheets had only a slight effect on superoxide anion generation in A549 cells (Figure 5E). In addition, we also investigated the generation of hydroxyl radicals using the HPF (hydroxyphenyl fluorescein) fluorescent probe in both cell lines. The results showed that the $\operatorname{Ti}_{0.8} \mathrm{O}_{2}$ nanosheets significantly generated hydroxyl radicals in both cell lines compared with the non-treated cells (Figure $5 \mathrm{H}, \mathrm{J}$ ). According to our obtained data, the pretreatment of cancer cell lines with a potent antioxidant for $1 \mathrm{~h}$ could not inhibit $\mathrm{H}_{2} \mathrm{O}_{2}$ damage, while the $\mathrm{Ti}_{0.8} \mathrm{O}_{2}$ nanosheets generated superoxide anion hydroxyl radicals in both cell lines. 

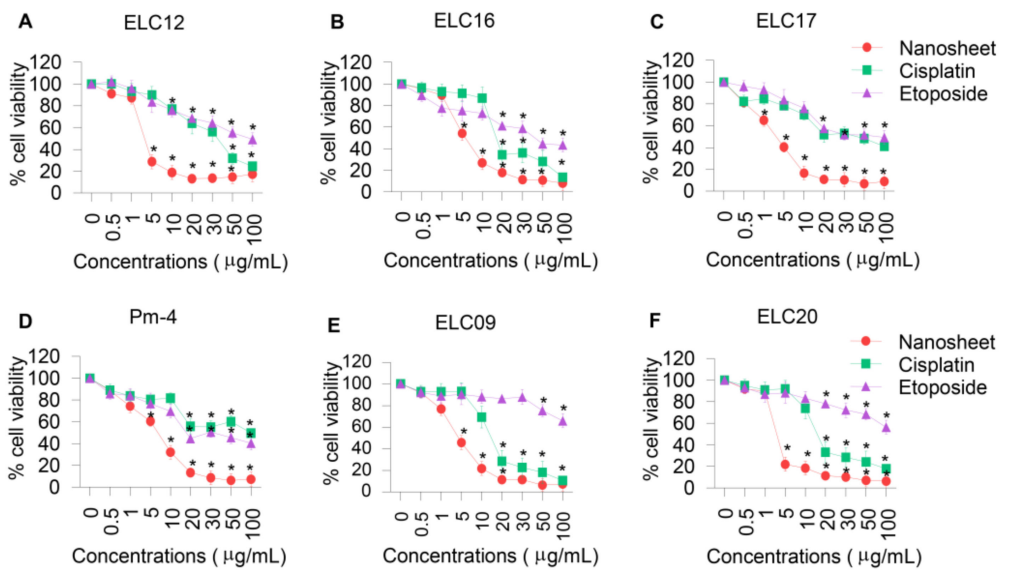

G

\begin{tabular}{cccc}
\hline & \multicolumn{3}{c}{$\mathrm{IC}_{50} \pm \mathrm{SEM}(\mu \mathrm{g} / \mathrm{mL})$} \\
\cline { 2 - 4 } Cell lines & $\begin{array}{c}\mathrm{Ti}_{0.8} \mathrm{O}_{2} \\
\text { nanosheets }\end{array}$ & Cisplatin & Etoposide \\
\hline PM-4 & $4.58 \pm 0.94$ & $>100$ & $>100$ \\
ELC09 & $3.75 \pm 2.01$ & $>20$ & $>13 \pm 0.53$ \\
ELC12 & $3.65 \pm 0.87$ & $30 \pm 0.87$ & $>100$ \\
\hline
\end{tabular}

\begin{tabular}{cccc}
\hline & \multicolumn{3}{c}{$\mathrm{IC}_{50} \pm \mathrm{SEM}(\mu \mathrm{g} / \mathrm{mL})$} \\
\cline { 2 - 4 } Cell lines & $\begin{array}{c}\mathrm{Ti}_{0.8} \mathrm{O}_{2} \\
\text { nanosheets }\end{array}$ & Cisplatin & Etoposide \\
\hline ELC16 & $4.08 \pm 1.05$ & $15 \pm 0.75$ & $83 \pm 1.05$ \\
ELC17 & $3.43 \pm 0.49$ & $51 \pm 0.39$ & $>100$ \\
ELC20 & $3.37 \pm 1.45$ & $12 \pm 0.95$ & $>100$ \\
\hline
\end{tabular}
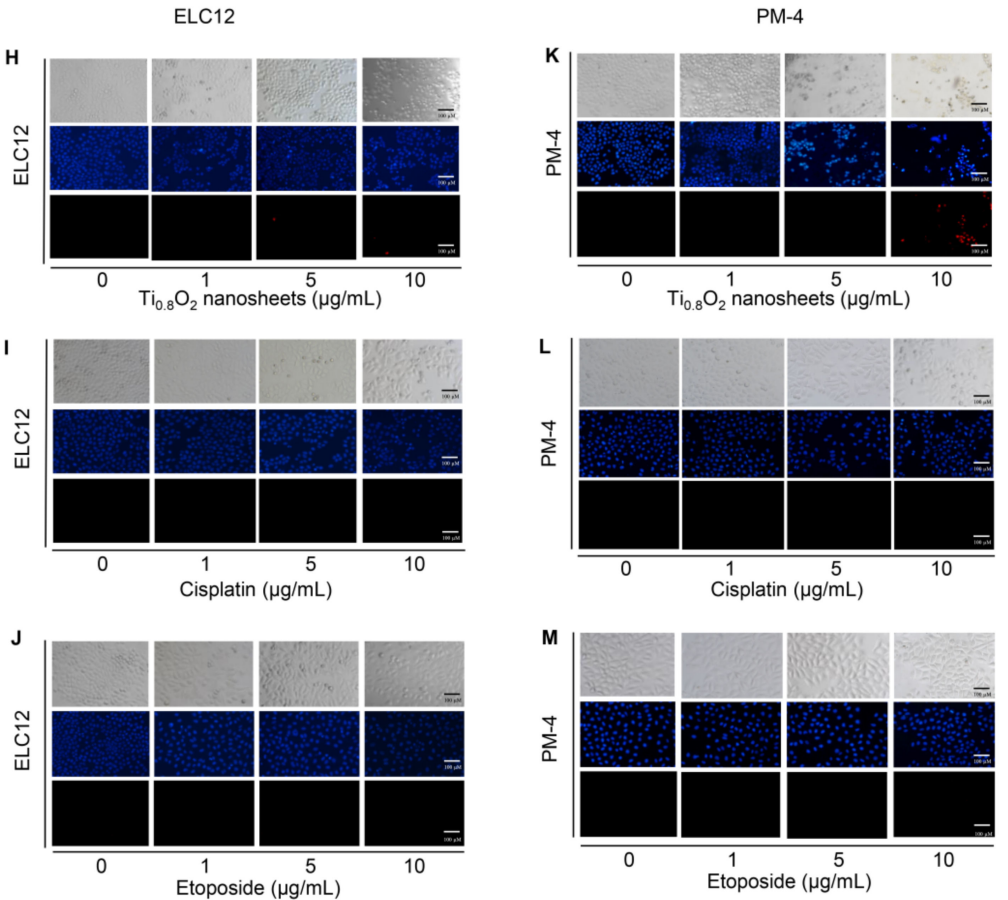

Figure 4. Cytotoxicity of the $\mathrm{Ti}_{0.8} \mathrm{O}_{2}$ nanosheets on malignant pleural effusion from advanced lung cancer patients. (A-F) Effect of the $\mathrm{Ti}_{0.8} \mathrm{O}_{2}$ nanosheets on the cell viability of malignant pleural effusion for $24 \mathrm{~h}$ using an MTT assay to determine the $\mathrm{IC}_{50}$ values; $(\mathrm{G})$ percentages of cell viability were determined using an MTT assay; (H-M) morphology of apoptotic nuclei stained with Hoechst 33342 dye and propidium iodide in cells treated with $\mathrm{Ti}_{0.8} \mathrm{O}_{2}$ nanosheets; cisplatin and etoposide were determined by visualization under a fluorescence microscope; the percentages of nuclear fragments and PI-positive cells were calculated. Data are shown as the mean $\pm \operatorname{SEM}(n=3) . * p<0.05$ versus non-treated control. 

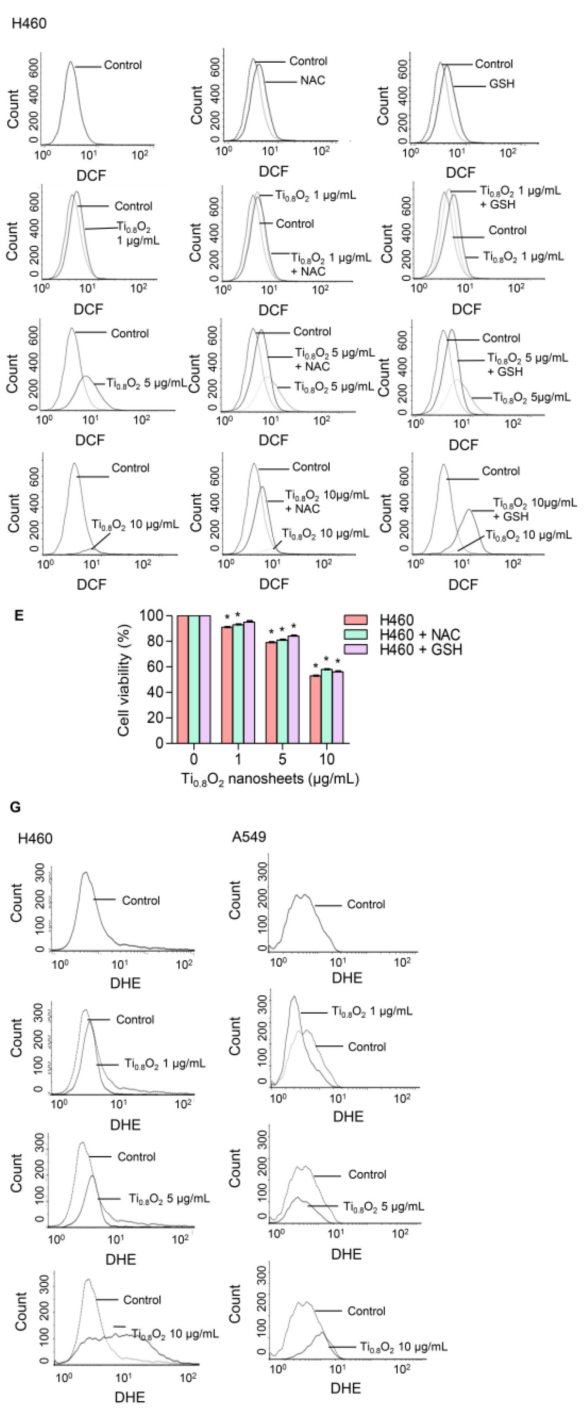

A549
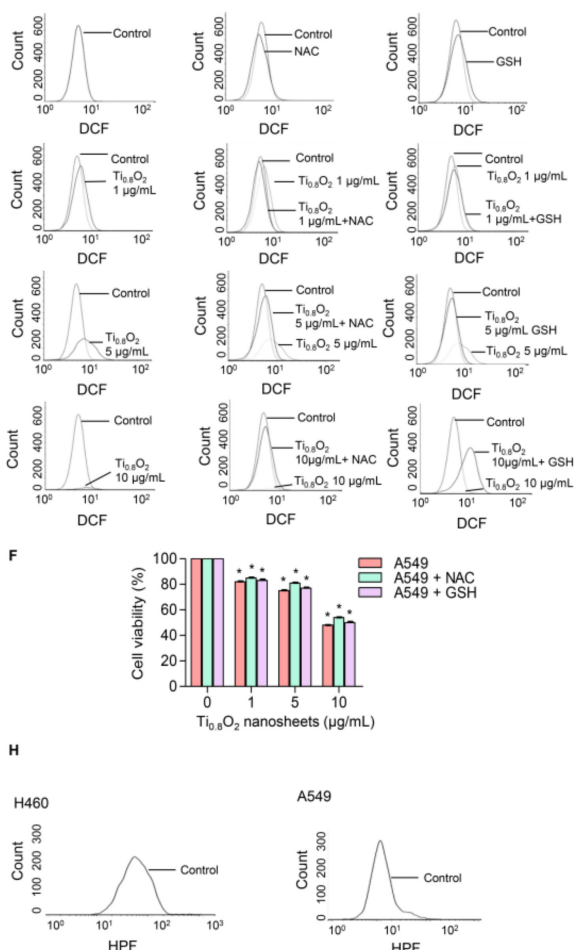

H
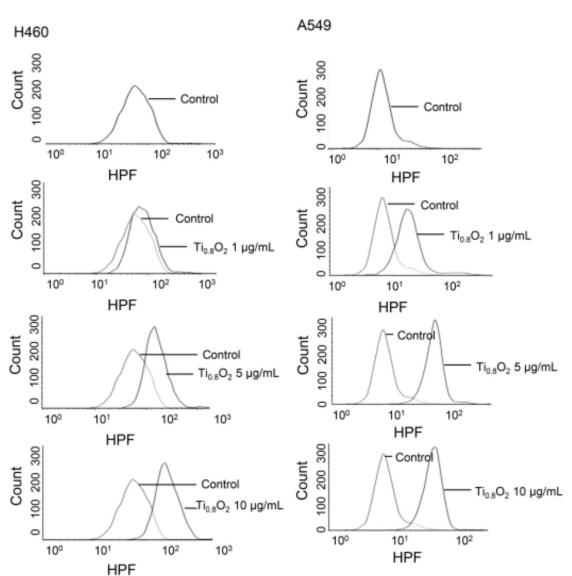

$\mathrm{H} 460$

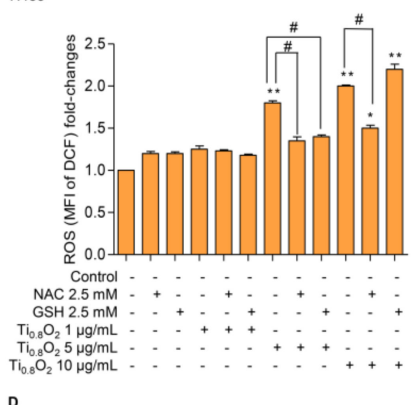

D

A549
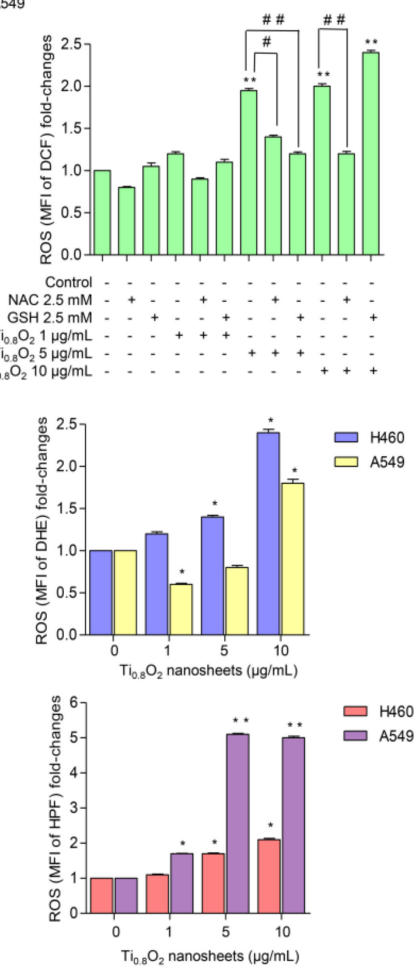

Figure 5. $\mathrm{Ti}_{0.8} \mathrm{O}_{2}$ nanosheets induced intracellular ROS in $\mathrm{H} 460$ and $\mathrm{A} 549$ cells. (A-D) The effect of $\mathrm{Ti}_{0.8} \mathrm{O}_{2}$ nanosheets $(0-10 \mathrm{~g} / \mathrm{mL})$ on intracellular ROS induction at $24 \mathrm{~h}$ in $\mathrm{H} 460$ and A549 cells was determined by flow cytometry with the fluorescent probe DCF $(10 \mu \mathrm{M})$. Cells were treated with $\mathrm{Ti}_{0.8} \mathrm{O}_{2}$ nanosheets $(0-10 \mu \mathrm{g} / \mathrm{mL})$ alone for $24 \mathrm{~h}$ or with the pretreatment of $2.5 \mathrm{mM} \mathrm{NAC}$ and $2.5 \mathrm{mM} \mathrm{GSH}$. ROS levels were calculated and presented as the mean fluorescence intensity (MFI); (E,F) effect of $\mathrm{Ti}_{0.8} \mathrm{O}_{2}$ nanosheets on cell viability in $\mathrm{H} 460$ and $\mathrm{A} 549$ cells at $24 \mathrm{~h}$ with the pretreatment of $2.5 \mathrm{mM}$ NAC or $2.5 \mathrm{mM} \mathrm{GSH}$ was determined by an MTT assay. Data are shown as the mean \pm SEM $(n=3) ;(\mathbf{G}, \mathbf{I})$ the effect of $\mathrm{Ti}_{0.8} \mathrm{O}_{2}$ nanosheets $(0-10 \mu \mathrm{g} / \mathrm{mL})$ on superoxide anion induction at $24 \mathrm{~h}$ in $\mathrm{H} 460$ and $\mathrm{A} 549$ cells was determined by flow cytometry with the fluorescent probe DHE $(10 \mu \mathrm{M})$. Superoxide anion levels were presented as mean fluorescence intensity (MFI); $(\mathrm{H}, \mathrm{J})$ the effect of $\mathrm{Ti}_{0.8} \mathrm{O}_{2}$ nanosheets $(0-10 \mu \mathrm{g} / \mathrm{mL})$ on hydroxyl radical induction at $24 \mathrm{~h}$ in $\mathrm{H} 460$ and A549 cells was determined by flow cytometry with the fluorescent probe HPF $(10 \mu \mathrm{M})$. Hydroxyl radical levels were calculated and indicated as the mean fluorescence intensity (MFI). All data are shown as the mean $\pm \operatorname{SEM}(n=3) . * p<0.05, * * p<0.01$ compared with the untreated control, and ${ }^{\#} p<0.05,{ }^{\# \#} p<0.01$ compared with the treated cells at the same concentration of $\mathrm{Ti}_{0.8} \mathrm{O}_{2}$ nanosheets.

\section{7. $\mathrm{Ti}_{0.8} \mathrm{O}_{2}$ Nanosheet-Mediated Peroxynitrite Induces Apoptosis in A549 and $\mathrm{H} 460$ Cells}

$\mathrm{NO}$ plays a role in apoptosis regulation through its ability to modulate ROS. The cytotoxic action of $\mathrm{NO}$ was demonstrated in several systems using diverse cell targets. Interestingly, the cytotoxicity of $\mathrm{NO}$ was shown to mediate via the interaction of $\mathrm{NO}$ with superoxide to form a highly reactive peroxynitrite $\left(\mathrm{ONOO}^{-}\right)$[33]. Consequently, we 
analyzed the cellular NO levels in response to the $\mathrm{Ti}_{0.8} \mathrm{O}_{2}$ nanosheets using DAF-FM DA as a fluorescent probe. The NO levels were found to be increased in a concentration-dependent manner (Figure 6A,C). Additionally, co-treatment with PTIO (a NO scavenger) and/or MnTBAP (a superoxide anion inhibitor) inhibited $\mathrm{Ti}_{0.8} \mathrm{O}_{2}$ nanosheet-induced cell death by increasing cell viability (Figure $6 \mathrm{~B}, \mathrm{D}$ ). The results suggest that $\mathrm{Ti}_{0.8} \mathrm{O}_{2}$ nanosheets induce cytotoxicity in cancer cell lines via the produced peroxynitrite. To confirm the previous results, we treated cells with $\mathrm{Ti}_{0.8} \mathrm{O}_{2}$ nanosheets and/or pretreated them with PTIO and/or MnTBAP and then determined the cellular NO level by staining with DAF-FM DA and then visualization under a fluorescence microscope. The results showed that the co-treatment with these inhibitors decreased peroxynitrite levels in all the cancer cells (Figure 6F). Then, we observed whether increased peroxynitrite was required for cell apoptosis induced by $\mathrm{Ti}_{0.8} \mathrm{O}_{2}$ nanosheets. The results showed that the co-treatment with these inhibitors was able to inhibit apoptosis cell death, as shown in Figure 6E. Collectively, these results indicated that peroxynitrite generation could play a role in mediating $\mathrm{Ti}_{0.8} \mathrm{O}_{2}$ nanosheet-induced cell apoptosis.

\section{8. $\mathrm{Ti}_{0.8} \mathrm{O}_{2}$ Nanosheet-Mediated Peroxynitrite Induces Apoptosis in A549 and H460 Cells via p53 Upregulation}

Since then, several cell types have been shown to undergo apoptosis in response to $\mathrm{NO}$ or peroxynitrite. A previous study reported that peroxynitrite was associated with p53 regulation to induce cancer cell death [33]. Therefore, we examined the effect of $\mathrm{Ti}_{0.8} \mathrm{O}_{2}$ nanosheets when combined with PTIO and/or MnTBAP. Western blot analysis was performed to evaluate the p53 protein levels after $10 \mu \mathrm{g} / \mathrm{mL} \mathrm{Ti}_{0.8} \mathrm{O}_{2}$ nanosheet treatment in all the cell lines. The results showed that the p53 protein levels in all the cell lines were significantly increased with the $\mathrm{Ti}_{0.8} \mathrm{O}_{2}$-nanosheets-alone treatment compared with those of the non-treatment control and another condition treatment (Figure 7A-C). Taken together, it could be concluded that the $\mathrm{Ti}_{0.8} \mathrm{O}_{2}$ nanosheets induced cancer cell death by the induction of peroxynitrite generation, which activated p53, leading to cancer cell apoptosis. The immunofluorescence staining results supported our finding that $\mathrm{Ti}_{0.8} \mathrm{O}_{2}$ nanosheets, in combination with PTIO and MnTBAP, caused a dramatic decrease in the levels of p53 and P-p53 in both cell lines (Figure 7D,E). These results indicate that the pro-apoptotic effect of $\mathrm{Ti}_{0.8} \mathrm{O}_{2}$ nanosheets for inducing $\mathrm{NO}$ is a result of the formation of peroxynitrite, which then induces p53-dependent apoptosis in all the cell lines.

\section{9. $\mathrm{Ti}_{0.8} \mathrm{O}_{2}$ Nanosheets Increase p53 Function but Not through $p 53$ Proteasomal Degradation}

In general, p53 functions as a tumor suppressor protein in response to oncogenic stress signals [34]. The essential role of p53 is emphasized by the fact that this protein is commonly deregulated or altered in human malignancies [35,36]. The activation of p53 initiates a variety of cellular responses that stop the cell cycle, induce senescence, and activate apoptosis. The key to the regulation of p53 is the control of its stability, which is mainly arranged through a network of ubiquitination reactions. We further evaluated the effect of the $\mathrm{Ti}_{0.8} \mathrm{O}_{2}$ nanosheets on p53 protein stability using the cycloheximide (CHX) chasing assay. $\mathrm{CHX}$ can inhibit protein biosynthesis and is widely used to investigate the half-life of proteins [37]. Therefore, $\mathrm{H} 460$ and $\mathrm{A} 549$ cells were treated with $\mathrm{Ti}_{0.8} \mathrm{O}_{2}$ nanosheets in the presence or absence of $\mathrm{CHX}$, and the level of p53 over time was determined. Figure 8A,B shows that in the condition where protein production was blocked, the $\mathrm{Ti}_{0.8} \mathrm{O}_{2}$ nanosheets increased the stability of the p53 protein. A difference was first detected at $90 \mathrm{~min}$ after $\mathrm{Ti}_{0.8} \mathrm{O}_{2}$ nanosheet treatment (Figure $8 \mathrm{~A}, \mathrm{~B}$ ). We also determined the p53 protein's half-life and found that the half-life of the p53 protein was approximately $60 \mathrm{~min}$ in the $\operatorname{Ti}_{0.8} \mathrm{O}_{2}$ nanosheet-treated cells; In contrast, in the non-treated control cells, the half-life was about 30-40 min (Figure 8C). 

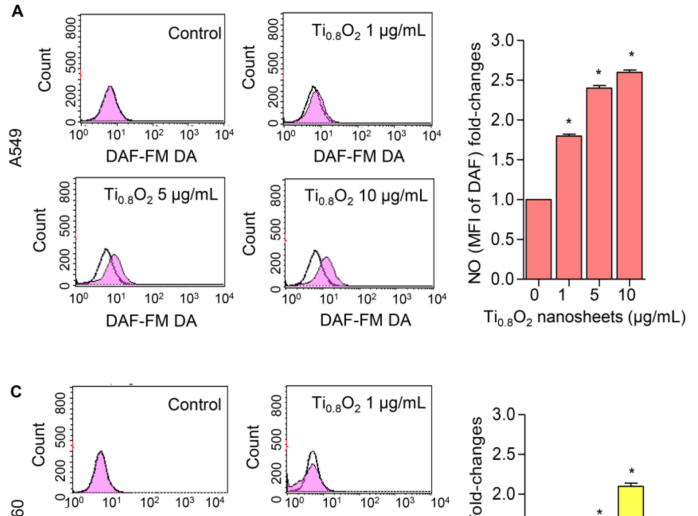

䏒

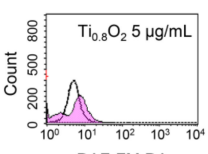

DAF-FM DA

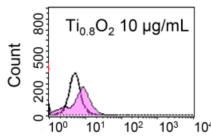

DAF-FM DA

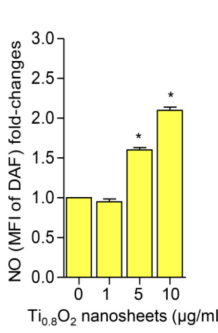

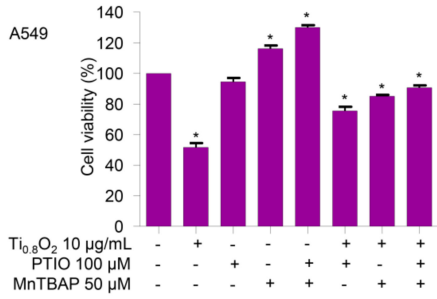

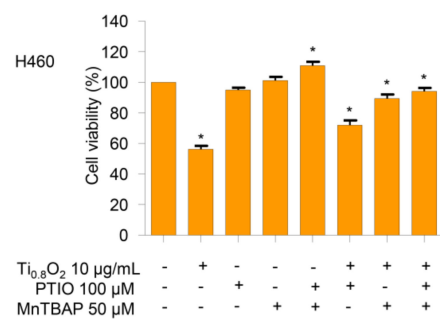

E
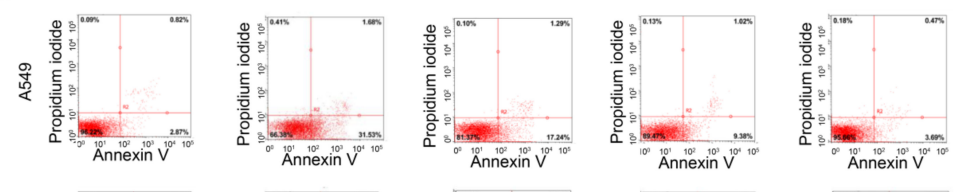

总
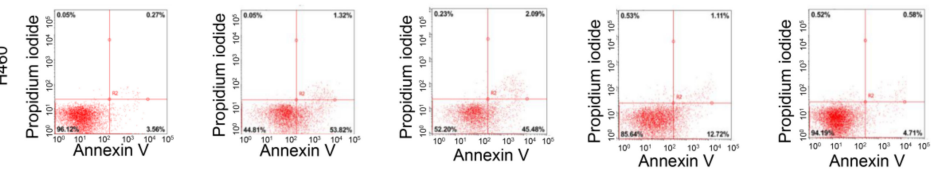

0

$\mathrm{Ti}_{08} \mathrm{O}_{2} 10 \mu \mathrm{g} / \mathrm{mL}$

$\mathrm{Ti}_{0.8} \mathrm{O}_{2} 10 \mu \mathrm{g} / \mathrm{mL}$
$+\mathrm{PTTO} 100 \mu \mathrm{M}$

$\begin{aligned} & \mathrm{Ti}_{0.8} \mathrm{O}_{2} 10 \mu \mathrm{g} / \mathrm{m} \\ + & \text { MnTBAP } 50 \mu \mathrm{MM}\end{aligned}$

$\mathrm{T}_{\mathrm{i}_{0}} \mathrm{O}_{2} 10 \mu \mathrm{g} / \mathrm{mL}$
+ PTIO $100 \mu \mathrm{M}$ MnTBAP $50 \mu \mathrm{M}$
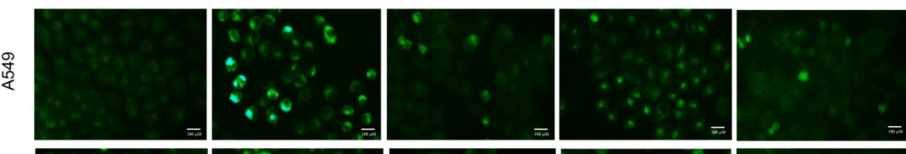

$\frac{8}{\stackrel{8}{I}}$
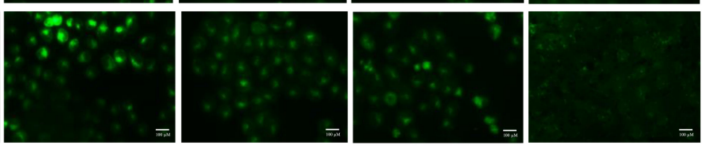

0

$\mathrm{Ti}_{0.8} \mathrm{O}_{2} 10 \mu \mathrm{g} / \mathrm{ml}$

$\mathrm{Ti}_{0.8} \mathrm{O}_{2} 10 \mu \mathrm{g} / \mathrm{mL}$
+PTIO $100 \mu \mathrm{M}$

$\mathrm{Ti}_{0.8} \mathrm{O}_{2} 10 \mu \mathrm{g} / \mathrm{mL}$
+ MnTBAP $50 \mu \mathrm{M}$

\section{$\mathrm{Ti}_{0.8} \mathrm{O}_{2} 10 \mu \mathrm{g} / \mathrm{mL}$
$+\mathrm{PTIO} 100 \mu \mathrm{M}$} + MnTBAP $50 \mu \mathrm{M}$

Figure 6. $\mathrm{Ti}_{0.8} \mathrm{O}_{2}$ nanosheets induced $\mathrm{NO}$ in $\mathrm{A} 549$ and $\mathrm{H} 460$ cells and mediated peroxynitrite generation in these cells. (A,C) Effect of $\mathrm{Ti}_{0.8} \mathrm{O}_{2}$ nanosheets on $\mathrm{NO}$ levels in A549 and $\mathrm{H} 460$ cells. Cells were treated with DAF-FM DA and various concentrations of $\mathrm{Ti}_{0.8} \mathrm{O}_{2}$ nanosheets $(0-10 \mu \mathrm{g} / \mathrm{mL})$ for $30 \mathrm{~min}$, and the peroxynitrite levels were determined at $3 \mathrm{~h}$ by flow cytometry. NO levels are presented as mean fluorescence intensity (MFI); (B,D) the cytotoxic effect of $\mathrm{Ti}_{0.8} \mathrm{O}_{2}$ nanosheets and the NO scavenger (PTIO) on $\mathrm{A} 549$ and $\mathrm{H} 460$ cells. Effect of $\mathrm{Ti}_{0.8} \mathrm{O}_{2}$ nanosheets and the NO scavenger (PTIO) on cell viability. Cells were treated with $\mathrm{Ti}_{0.8} \mathrm{O}_{2}$ nanosheets $(10 \mu \mathrm{g} / \mathrm{mL})$ in the presence or absence of pretreatment with a NO scavenger (PTIO) $(100 \mu \mathrm{M})$ or pretreatment with a superoxide inhibitor (MnTBAP) $(50 \mu \mathrm{M})$ for $24 \mathrm{~h}$ by MTT assay; (E) apoptotic and necrotic cells were determined using annexin V-FITC/PI staining with flow cytometry; (F) cellular NO level stained with DAF-FM DA in cells treated with $\mathrm{Ti}_{0.8} \mathrm{O}_{2}$ nanosheets $(10 \mu \mathrm{g} / \mathrm{mL})$ or pretreated with PTIO $(100 \mu \mathrm{M})$ or MnTBAP $(50 \mu \mathrm{M})$ were determined by visualization under a fluorescence microscope. All data are shown as the mean $\pm \operatorname{SEM}(n=3) . * p<0.05$ compared with the untreated control. 

A549
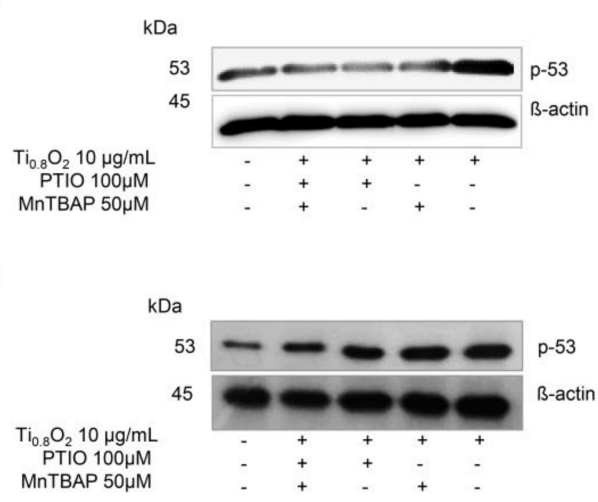

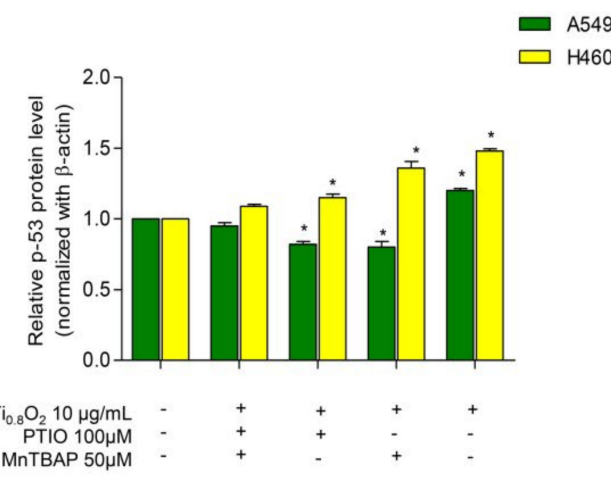

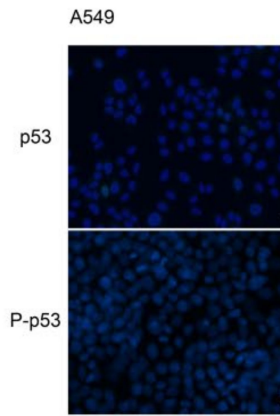

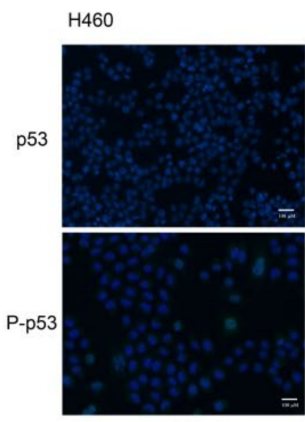

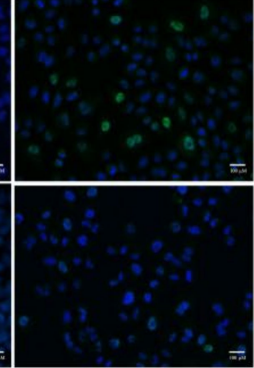

PTIO $100 \mu \mathrm{M}$

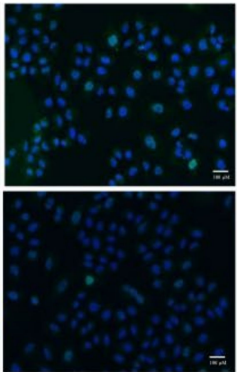

MnTBAP $50 \mu \mathrm{M}$

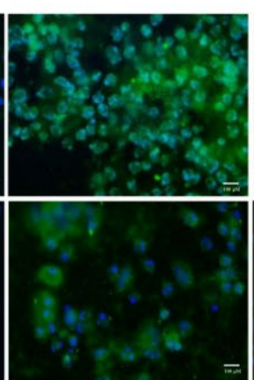

$\mathrm{Ti}_{0.8} \mathrm{O}_{2} 10 \mu \mathrm{g} / \mathrm{mL}$

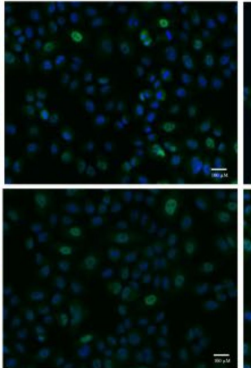

$\mathrm{Ti}_{0.8} \mathrm{O}_{2} 10 \mu \mathrm{g} / \mathrm{mL}$ $\mathrm{T}_{0.8} 8210 \mu \mathrm{g} / \mathrm{mL}$
+ PTIO $100 \mu \mathrm{M}$

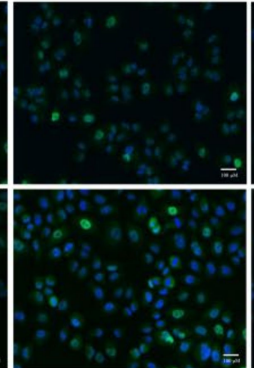

$\mathrm{Ti}_{0.8} \mathrm{O}_{2} 10 \mu \mathrm{g} / \mathrm{mL}$ $\begin{aligned} & \mathrm{Ti}_{0.8} \mathrm{O}_{2} 10 \mu \mathrm{g} / \mathrm{mL} \\ + & \text { MnTBAP } 50 \mu \mathrm{M}\end{aligned}$ $\mathrm{I}_{0.8} \mathrm{O}_{2} 10 \mu \mathrm{g} / \mathrm{mL}$
+ PTIO $100 \mu \mathrm{M}$ + MnTBAP $50 \mu \mathrm{M}$
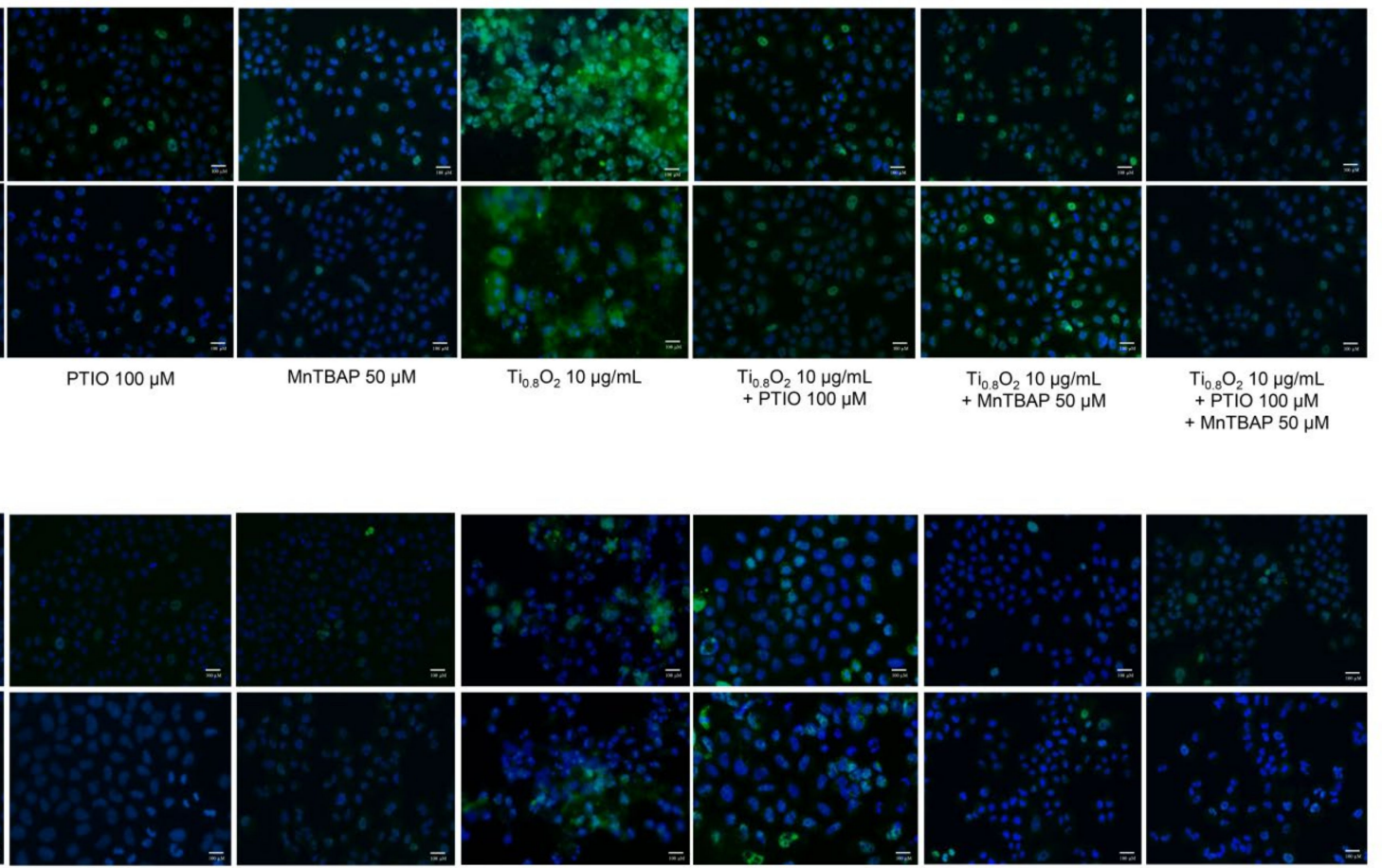

PTIO $100 \mu \mathrm{M}$

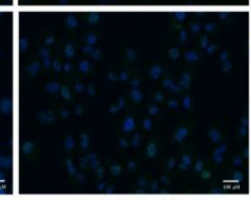

MnTBAP $50 \mu \mathrm{M}$

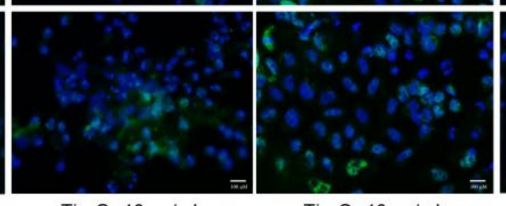

$\mathrm{Ti}_{0.8} \mathrm{O}_{2} 10 \mu \mathrm{g} / \mathrm{mL}$

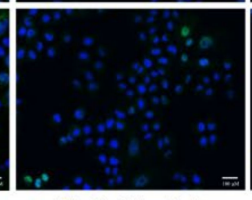

$\mathrm{Ti}_{0.8} \mathrm{O}_{2} 10 \mu \mathrm{g} / \mathrm{mL}$
+ MnTBAP $50 \mu \mathrm{M}$

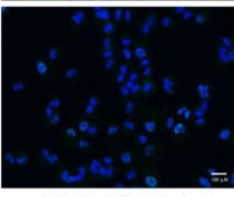

$\mathrm{Ti}_{0.8} \mathrm{O}_{2} 10 \mu \mathrm{g} / \mathrm{mL}$
+ PTIO $100 \mu \mathrm{M}$ + MnTBAP $50 \mu \mathrm{M}$

Figure 7. $\mathrm{Ti}_{0.8} \mathrm{O}_{2}$ nanosheets associated with apoptosis in A549 and $\mathrm{H} 460$ cells via p53 upregulation. (A,B) Peroxynitritepotentiated cell apoptosis through the 553 protein was measured by Western blot analysis; (C) blots were reprobed with $\beta$-actin to confirm the equal loading of samples. The relative protein levels were calculated by densitometry. Data are shown as the mean $\pm \operatorname{SEM}(n=3) . * p<0.05$ versus non-treated control. $(\mathbf{D}, \mathbf{E})$ the expressions of p53 and P-p53 were analyzed by immunofluorescence staining in A549 and H460 cells.

Moreover, the turnover of the p53 protein is tightly regulated by ubiquitin-proteasome degradation. Thus, we used the specific proteasome inhibitor (MG132) to investigate whether the $\mathrm{Ti}_{0.8} \mathrm{O}_{2}$ nanosheets increased p53 stability via the inhibition of proteasomal degradation. Co-immunoprecipitation was also used to test the premise of ubiquitinmediated p53 degradation in $\mathrm{H} 460$ and A549 cells after treatment with $10 \mu \mathrm{g} / \mathrm{mL}$ of $\mathrm{Ti}_{0.8} \mathrm{O}_{2}$ nanosheets and in non-treated control cells for $1 \mathrm{~h}$. Figure $8 \mathrm{D}$,E shows that the polyubiquitination of p53 was slightly diminished after $\mathrm{Ti}_{0.8} \mathrm{O}_{2}$ nanosheet treatment when compared with control. 


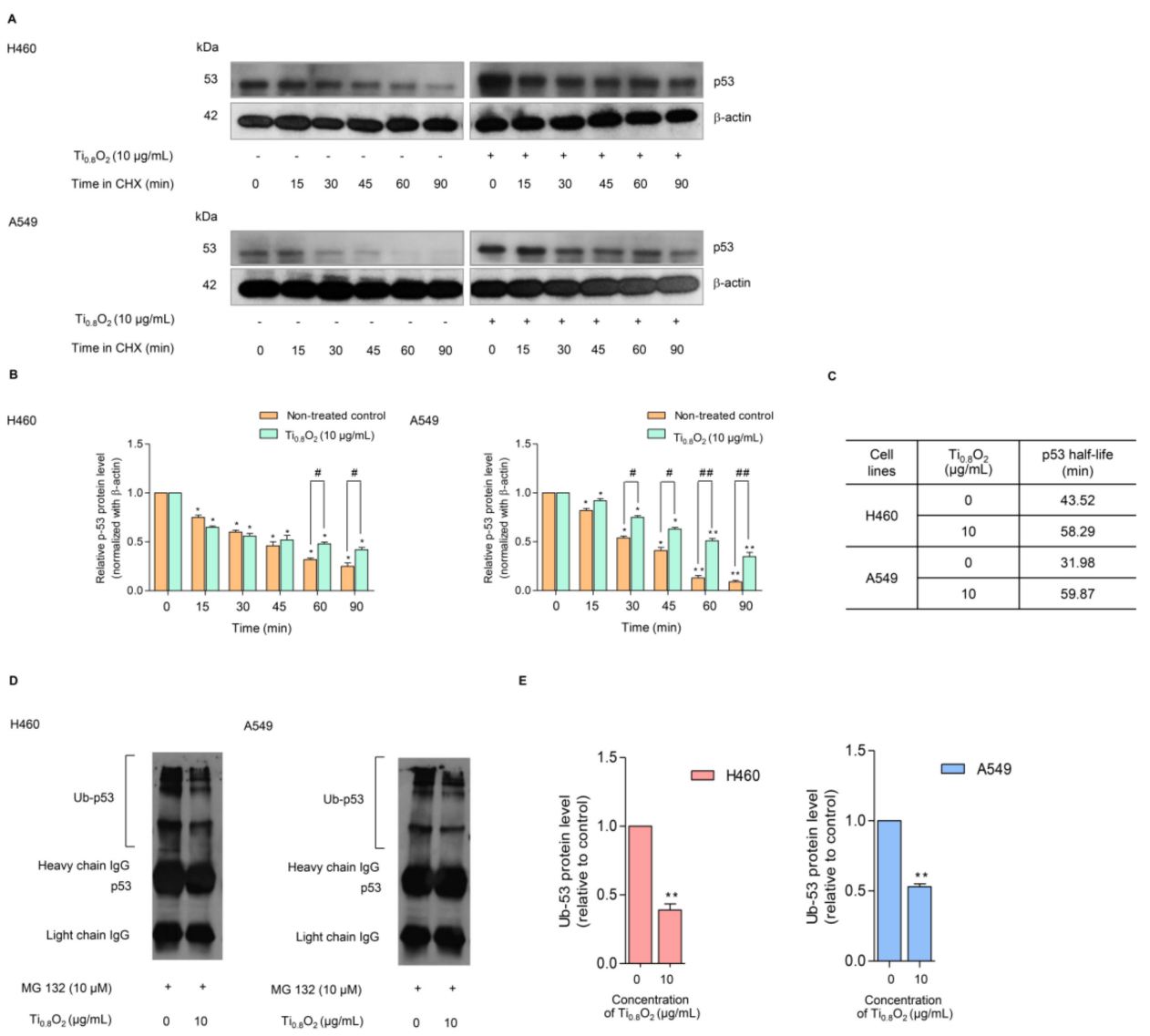

Figure 8. Effect of $\mathrm{Ti}_{0.8} \mathrm{O}_{2}$ nanosheets on the p53 level and proteasomal degradation. (A) The cycloheximine (CHX) chasing assay was performed to determine the half-life of p53. $\mathrm{H} 460$ and A549 cell lines were treated with $50 \mu \mathrm{g} / \mathrm{mL}$ of $\mathrm{CHX}$ with or without $10 \mu \mathrm{g} / \mathrm{mL} \mathrm{Ti}_{0.8} \mathrm{O}_{2}$ nanosheets. Western blot analysis was used to determine the p53 protein level; (B) the relative p53 protein levels were calculated and compared with the control group at $0 \mathrm{~min}$; (C) the half-lives of the p53 protein of H460 and A549 cells were calculated; (D) H460 and A549 cells were pretreated with $10 \mu \mathrm{M}$ MG132 for 30 min, followed by treatment with $10 \mu \mathrm{g} / \mathrm{mL} \mathrm{Ti}_{0.8} \mathrm{O}_{2}$ nanosheets for $60 \mathrm{~min}$. The protein lysates were collected, and the p53 protein was pulled down using p53 antibodies. The levels of the ubiquitin-p53 protein complex were determined by Western blot analysis.; (E) p53-ubiquitin complexes were quantified by densitometry. The relative protein levels are reported $(n=3) . * p<0.05$, $* * p<0.01$ compared with the untreated control at $0 \mathrm{~min}$, and ${ }^{\#}<0.05,{ }^{\# \#} p<0.01$ compared with the untreated control at the same time.

\subsection{S-Nitrosylation in the Regulation of Stability of the Tetrameric p53 Protein-Protein Complex}

$\mathrm{NO}$ exerts its effects via the formation of $S$-nitrosylation of cysteine (Cys) residues. $S$-nitrosylation is a significant post-translational modification that affects p53 functionality [14]. S-nitrosylation of a single Cys within HDM2 inhibits p53 binding and thereby stabilizes p53 and activates p53-dependent transcription [38]. We tested whether peroxynitrite may directly control p53 by $S$-nitrosylation and the activation of p53. To evaluate the structural stability of the p53 core domain tetramer (Figure 9A), the number of intermolecular hydrogen bonds formed between each monomer at the protein-protein interface was monitored along with the simulation time. Note that a hydrogen bond is defined by the following geometric criteria: (i) the distance between the hydrogen bond donor

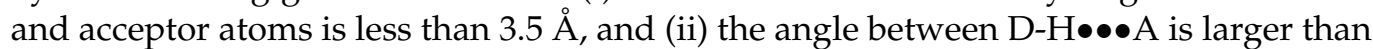
$120^{\circ}$. The obtained results showed that there was an average of $\sim 10 \pm 2$ hydrogen bonds steadily formed over the course of the simulation time (Figure 9B, top). This observation suggested that our simulation model was highly stable. Therefore, 100 equilibrated MD snapshots, extracted from the last 20 ns, were used for further analysis in terms of the $\Delta G_{\text {bind }}^{\text {residue }}$ calculation. 


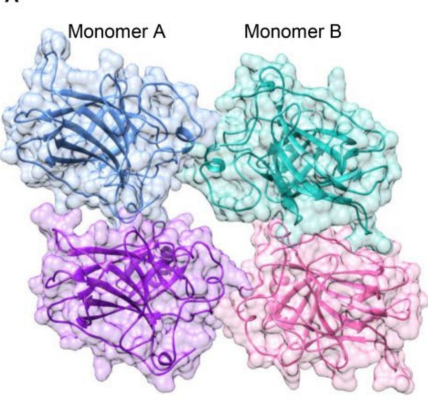

Monomer C
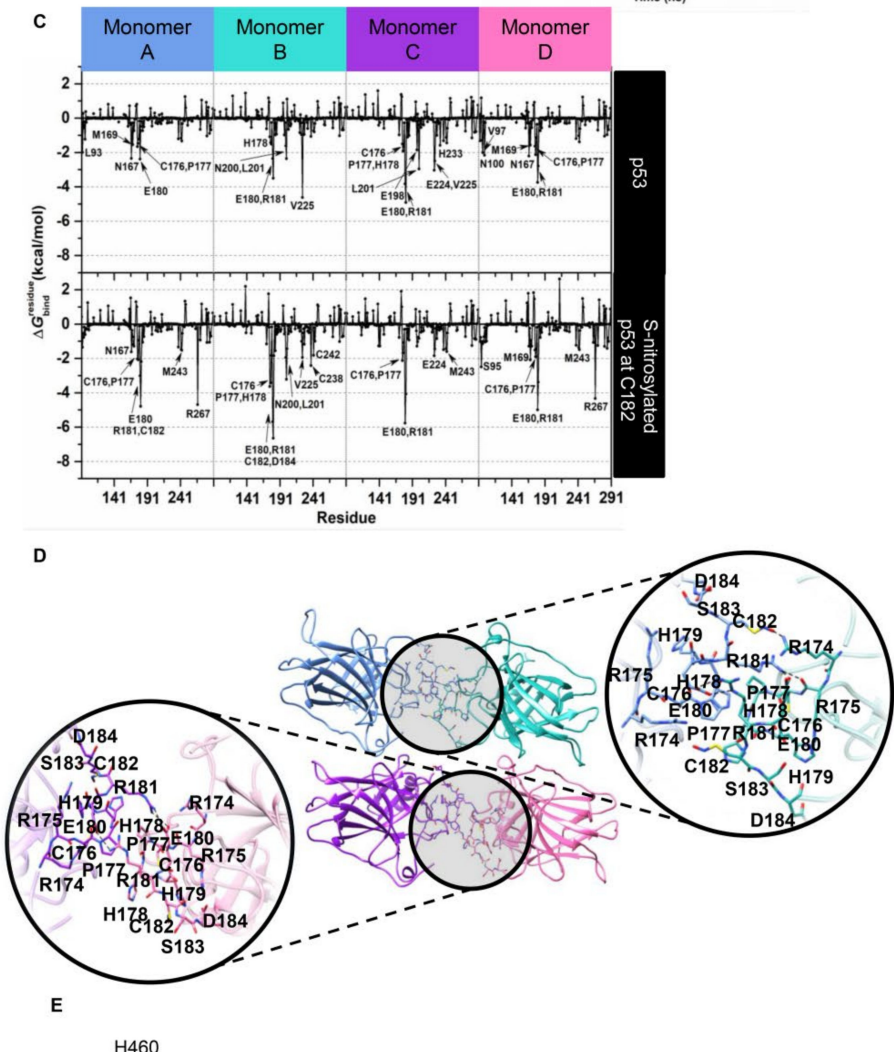

$\mathrm{H} 460$

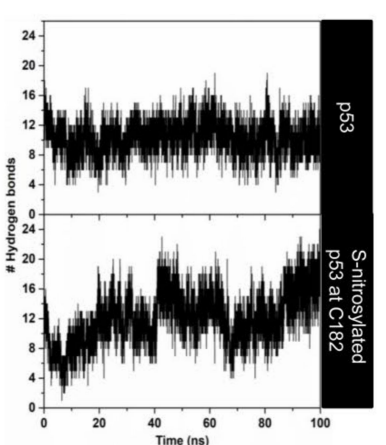

53
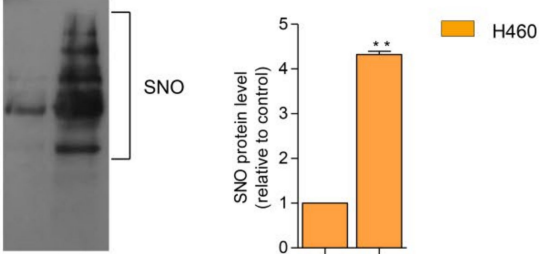

$\mathrm{Ti}_{0.8} \mathrm{O}_{2}(\mu \mathrm{gg} / \mathrm{mL}) \quad 0 \quad 10$

$\mathrm{Ti}_{0.8} \mathrm{O}_{2}(\mu \mathrm{g} / \mathrm{mL}) \quad 0 \quad 10$

Figure 9. S-nitrosylation in the regulation of p53 stability. (A) Three-dimensional (3D) structure of the tetrameric p53 core domain without DNA bound (PDB ID: 3KMD); (B) time evolution of the total number of intermolecular hydrogen bonds formed between each monomer of the 553 core domain and its adjacent monomer; $(\mathrm{C})$ the plot of $(\mathrm{kcal} / \mathrm{mol})$ of the p53 tetramer for the native form (top) and the C182 S-nitrosylation (bottom) system; (D) the representative 3D structure taken from the last MD snapshot of the $S$-nitrosylation system, with hydrogen bonds and electrostatic interactions represented by black dashed lines; (E) $S$-nitrosylated proteins determined by Pierce $S$-nitrosylation Western blot assay. Relative-to-control protein levels are reported $(n=3)$. $* * p<0.01$ compared with the untreated control at the same time. 
The $\Delta G_{\text {bind }}^{\text {residue }}$ value was then calculated to verify the crucial amino acids involved in protein binding at the interface region of each monomer. The total contributing energy from each amino acid for the protein-protein complex is shown in Figure 9C (top), where the positive and negative $\Delta G_{\text {bind }}^{\text {residue }}$ values are associated with protein destabilization and stabilization, respectively. It is noteworthy that only amino acids exhibiting a $\Delta G_{\text {bind }}^{\text {residue }}$ of $<-1.5 \mathrm{kcal} / \mathrm{mol}$ were marked as the key binding residues. The results showed that the crucial residues (L93, N167, M169, C176, P177, and E180 for monomer A; H178, E180, R181, N200, L201, and V225 for monomer B; C176, P177, H178, E180, R181, E198, L201, E224, V225, and H233 for monomer C; V97, N100, N167, M169, C176, P177, E180, and R181 for monomer D) played a pivotal role in the tetrameric protein-protein stabilization. Based on this calculation and upon visual inspection, it can be assumed that the cysteine residue within the protein-protein interface, particularly C182, is most likely to be a critical residue, which would be expected to be related to the $S$-nitrosylation site and, consequently, would lead to an increase in protein stability. To clarify such a hypothesis, the influence of $S$ nitrosylation on the $\mathrm{C} 182$ residue of $\mathrm{p} 53$ upon its binding interaction with each monomeric p53 was investigated by means of MD simulation, as per the native p53 system. The simulation indicated that the total number of intermolecular hydrogen bonds between four monomeric proteins was slightly increased over the whole simulation, with an average value of $\sim 12 \pm 2$ hydrogen bonds, particularly in the last $10 \mathrm{~ns}$ (90-100 ns), in which the number of hydrogen bonds was found to be up to $\sim 20$ (Figure 9B, bottom). This reflected that the $S$-nitrosylated C182 resulted in higher stability of the tetrameric protein-protein complex compared to the native p53. In addition, the occurrence of C182 S-nitrosylation appeared to induce the surrounding residues, located in the interface region, to bind more tightly to each other, especially residues 176-186 (Figure 9C (bottom) and Figure 9D). Among these amino acids, the lowest $\Delta G_{\text {bind }}^{\text {residue }}$ value $(\sim-5$ to $-7 \mathrm{kcal} / \mathrm{mol})$ was observed for residue R181, most likely owing to the indirect stabilizing effect of the $S$-nitrosylation at C182. This was probably one of the reasons why the S-nitrosylation culminated in the higher stability of p53, as observed in the experimental data.

To confirm the effect of such a nanosheet in the induction of $S$-nitrosylation in the cells, we further evaluated the induction of $S$-nitrosylated proteins in response to $\mathrm{Ti}_{0.8} \mathrm{O}_{2}$ nanosheets. Specific $S$-nitrosylated protein detection was done using the Pierce $S$-nitrosylation Western blot kit assay, as described in Section 2. The results revealed that $S$-nitrosylated proteins were dramatically increased in the $\mathrm{Ti}_{0.8} \mathrm{O}_{2}$-treated cells compared with the non-treated control group (Figure 9E). Taken together, the findings highlight the impact of $\mathrm{Ti}_{0.8} \mathrm{O}_{2}$-induced peroxynitrite in promoting $S$-nitrosylation and increasing the stability of the tetrameric p53 protein-protein complex, which is responsible for apoptosis cell death in NSCLC.

\section{Discussion}

Lung cancer remains the major cause of cancer death worldwide. Nowadays, nanomaterials are showing remarkable potential to aid the diagnosis and treatment of cancer by enabling the more effective targeting of tumors [39]. Previous studies have revealed that nanomaterials can selectively sink into solid tumors, whereby they increase the bioavailability and decrease the toxicity of the encapsulated cytotoxic agents [39,40]. $\mathrm{Ti}_{0.8} \mathrm{O}_{2}$ (an emerging $2 \mathrm{D}$ analog of $\mathrm{TiO}_{2}$ ) nanosheets can be derived from the potassium zinc titanate precursor $\mathrm{K}_{0.8} \mathrm{Zn}_{0.4} \mathrm{Ti}_{1.6} \mathrm{O}_{4}$. The planar surface and functional motifs of such $2 \mathrm{D}$ inorganic nanosheets can be modified using a surface engineering process involving chemical bonding or physical adsorption [22], which facilitates applications in physiological environments, through, e.g., their biostability improvement, site-specific targeting capability, and multiple theranostic functions to facilitate oncological applications [18,40,41].

Although $\mathrm{TiO}_{2}$ nanoparticles and nanotubes have been extensively investigated for their possible applications [41,42], to the best of our knowledge, there have been limited studies on $\mathrm{Ti}_{0.8} \mathrm{O}_{2}$ nanosheets. Consequently, here, we show for the first time that $\mathrm{Ti}_{0.8} \mathrm{O}_{2}$ nanosheets can distinctively induce anti-cancer activity in human non-small cell lung cancer 
cells and advanced lung cancer cells from patients. This effect was demonstrated in several lung cancer lines in comparison to common chemotherapeutic drugs used in lung cancer patients. The $\mathrm{Ti}_{0.8} \mathrm{O}_{2}$ nanosheets significantly increased cancer cell death in a concentrationdependent manner (Figure 2). Moreover, the $\mathrm{Ti}_{0.8} \mathrm{O}_{2}$ nanosheets also mediated apoptosis in lung cancer cells in a concentration-dependent manner (Figure 2I-N). Moreover, SEM analysis revealed that $10 \mu \mathrm{g} / \mathrm{mL} \mathrm{Ti}_{0.8} \mathrm{O}_{2}$ nanosheets altered cell morphology, while TEM analysis for the characterization of the $\mathrm{Ti}_{0.8} \mathrm{O}_{2}$ nanosheets in cells showed that the $\mathrm{Ti}_{0.8} \mathrm{O}_{2}$ nanosheets could appropriately disperse into $\mathrm{H} 460$ cells more easily than in DP cells (Figure 3B). A previous study showed that various types of nanoparticles (NPs), such as copper oxide nanoparticles, could be used to induce anti-cancer activity in cancer cells [43]. Next, we further examined whether the $\mathrm{Ti}_{0.8} \mathrm{O}_{2}$ nanosheets could induce cell apoptosis in $\mathrm{H} 460$ and $\mathrm{A} 549$ cells. We found that the treatment of lung cancer cells with $\mathrm{Ti}_{0.8} \mathrm{O}_{2}$ nanosheets resulted in a significant induction of p53, which may, at least in part, play a role in $\mathrm{Ti}_{0.8} \mathrm{O}_{2}$ nanosheet-mediated apoptosis (Figure 3C,D). Consistent with our findings, a previous study showed that $\mathrm{FePt} / \mathrm{GO}$ nanosheets suppressed proliferation and induced apoptosis in H1975 cells, and silver nanoparticles induced apoptosis in human colon cancer cells mediated by p53 [44,45].

Most cancers possess aberrant or disrupted p53 pathways. Intervention to restore or enhance p53 activity is a promising cancer treatment strategy [46]. Interestingly, in this study, we further confirmed that $\mathrm{Ti}_{0.8} \mathrm{O}_{2}$ nanosheets also had cytotoxicity in patient-derived primary lung cancer cells, with a lower $\mathrm{IC}_{50}$ compared to some other first-line chemotherapeutic drugs tested (Figure 4). In addition, we have provided supportive information explaining that the cancer cell selectivity of $\mathrm{Ti}_{0.8} \mathrm{O}_{2}$ nanosheets may be caused by the generation of superoxide anions, similar to findings in a previous study [20]. Another previous study suggested that the effect of nanosilver on apoptosis was via ROS generation and the JNK-dependent pathway [47]. In addition, aminoflavone (AF) has been demonstrated to cause selective cell death induction in breast cancer cells, with minimal toxicity to normal breast cells. Aminoflavone caused an ROS increase, which is linked with the activation of caspase 3 and apoptosis, which can be prevented by the pretreatment of the cells with $\mathrm{N}$-acetyl-L-cysteine (NAC) [48,49]. However, the generation of ROS was not associated with lung cancer cell death when the cells were pretreated with NAC or GSH, and the cell viability of the cancer cells could not be reversed (Figure 5C,D). This result suggests that the $\mathrm{Ti}_{0.8} \mathrm{O}_{2}$ nanosheets may generate other ROS for inducing cell death. Therefore, we investigated the $\mathrm{NO}$ level in lung cancer cells because its activity could be associated with cell death, as previously described [16]. The results showed that the NO levels were increased in a concentration-dependent manner (Figure 6A,C). Additionally, co-treatment of $\mathrm{Ti}_{0.8} \mathrm{O}_{2}$ nanosheets with PTIO (NO scavenger) or MnTBAP (superoxide anion inhibitor) inhibited $\mathrm{Ti}_{0.8} \mathrm{O}_{2}$ nanosheet-induced cell death by increasing cell viability. Much evidence has demonstrated that the direct toxicity of NO is modest but can be greatly enhanced by reacting with the superoxide anion to form peroxynitrite $\left(\mathrm{ONOO}^{-}\right)$, which can directly damage DNA and attenuate DNA repair [50,51].

p53 is a tumor suppressor gene, regulating apoptosis and cell cycle arrest in cells that have damaged DNA. We found that the generation of peroxynitrite after treatment with $\mathrm{Ti}_{0.8} \mathrm{O}_{2}$ nanosheets upregulated the expression of $\mathrm{p} 53$-mediated apoptosis (Figure 7). The data support the hypothesis that peroxynitrite contributes to the tumorigenic properties of p53 mutations. Peroxynitrite was found to induce mitochondrial permeability transition changes and promote apoptosis in cell-free systems containing mitochondria [52]. The degradation of p53 in normal cells is regulated through ubiquitination by the E3 ubiquitin ligase $\mathrm{Mdm} 2$ [53]. In this study, we found that under $\mathrm{Ti}_{0.8} \mathrm{O}_{2}$ nanosheet treatment, the half-life of p53 was dramatically increased. The cycloheximide-based assay showed that the half-life of p53 in response to $10 \mu \mathrm{g} / \mathrm{mL} \mathrm{Ti}_{0.8} \mathrm{O}_{2}$ nanosheets was about $60 \mathrm{~min}$ in comparison to 30-40 min in non-treated control cells (Figure 8A-C). After applying the selective proteasome inhibitor (MG132), we monitored the levels of the p53-ubiquitin complex and found that the formation of the complex was dramatically decreased in 
the $\mathrm{Ti}_{0.8} \mathrm{O}_{2}$ nanosheet-treated cancer cells (Figure $8 \mathrm{D}, \mathrm{E}$ ). Here, we have revealed novel information regarding the role of reactive nitrogen species, especially peroxynitrite, in the regulation of p53 tetramerization. Our results showed that when the cells were exposed to the nanosheets, the intracellular level of peroxynitrite was highly upregulated (Figure 6). Concomitantly, increased p53 was detected (Figure 7A-C) with the decrease in the p53ubiquitin complex (Figure 8D,E), implying that the upregulation of p53 occurs as a result of preventing its degradation process.

Peroxynitrite is considered an important biological inducer via its direct interaction with protein in S-nitrosylation. S-nitrosylation is a rapid interaction wherein NO is attached to a thiol moiety of the target protein, forming $S-\mathrm{NO}$ at the cysteine amino acid [54]. More than 1000 proteins have been found as the targets of $S$-nitrosylation [55], and it was noted that such protein modification resulted in a profound alteration of protein-protein interaction, protein function, protein localization, and protein stability [56]. Cellular stress, such as through cisplatin (CDDP) treatment, activates and stabilizes p53 via phosphorylation at the sites of Ser 15 and/or Ser 20, subsequently blocking p53-Mdm2 interaction and suppressing p53 degradation [57].

The p53 protein plays a crucial role as a transcription factor regulating the expression of many proteins controlling cell arrest and apoptosis [58]. The p53 protein contains a tetramerization domain (p53TD) and a DNA-binding domain (p53DBD) which are important for protein functions [59]. Interestingly, evidence indicates that the activity of the p53 protein is highly dependent on tetrameric complex formation and complex stability [60]. Therefore, molecules capable of stabilizing the tetrameric form of the proteins could be promising therapeutical tools. Furthermore, we report additional studies on the role of hydrogen bond interactions in protein stability and the key binding residues of p53 to direct the effect of S-nitrosylation (Figure 9). In globular proteins, there are intermolecular hydrogen bonds between the protein and water molecules and between water molecules that are bound with the proteins [61]. Here, we used computational tools to predict the point of $S$-nitrosylation on the p53 protein and found that peroxynitrite may directly control p53 by $S$-nitrosylation to stabilize the tetrameric structure of this protein. To estimate the contribution of these hydrogen bonds to the conformational stability of a protein compared with that of the native p53 and S-nitrosylation of p53 [62], we investigated the relationship between $S$-nitrosylation and the increase in p53 stability. We identified the $\mathrm{H}$-bond intermolecular interactions between a monomer of native p53 compared to its $S$-nitrosylation form and found higher stability of the tetrameric proteinprotein complex in comparison to the native p53, especially regarding the reactivity of the cysteine at residue 182 in p53. The high reactivity of specific cysteine thiol groups in p53 is likely important for the regulation of p53 and its degradation pathways [38]. Moreover, peroxynitrite has been shown to activate the opening of mitochondrial pores that release cytochrome $\mathrm{c}$ into the cytoplasm [63]. According to our results, we found that peroxynitrite induces p53 stability and increases the activation of Bax and, subsequently, caspase 3 . These changes are all hallmarks of cell death (Figure 10). Furthermore, the nanosheets were shown to generate peroxynitrite in aggressively driven mechanisms, including the process for the $S$-nitrosylation of p53 for protein stabilization. This novel finding on the role of $\mathrm{Ti}_{0.8} \mathrm{O}_{2}$ nanosheets in p53-mediated apoptosis may have important implications in cancer treatment. 


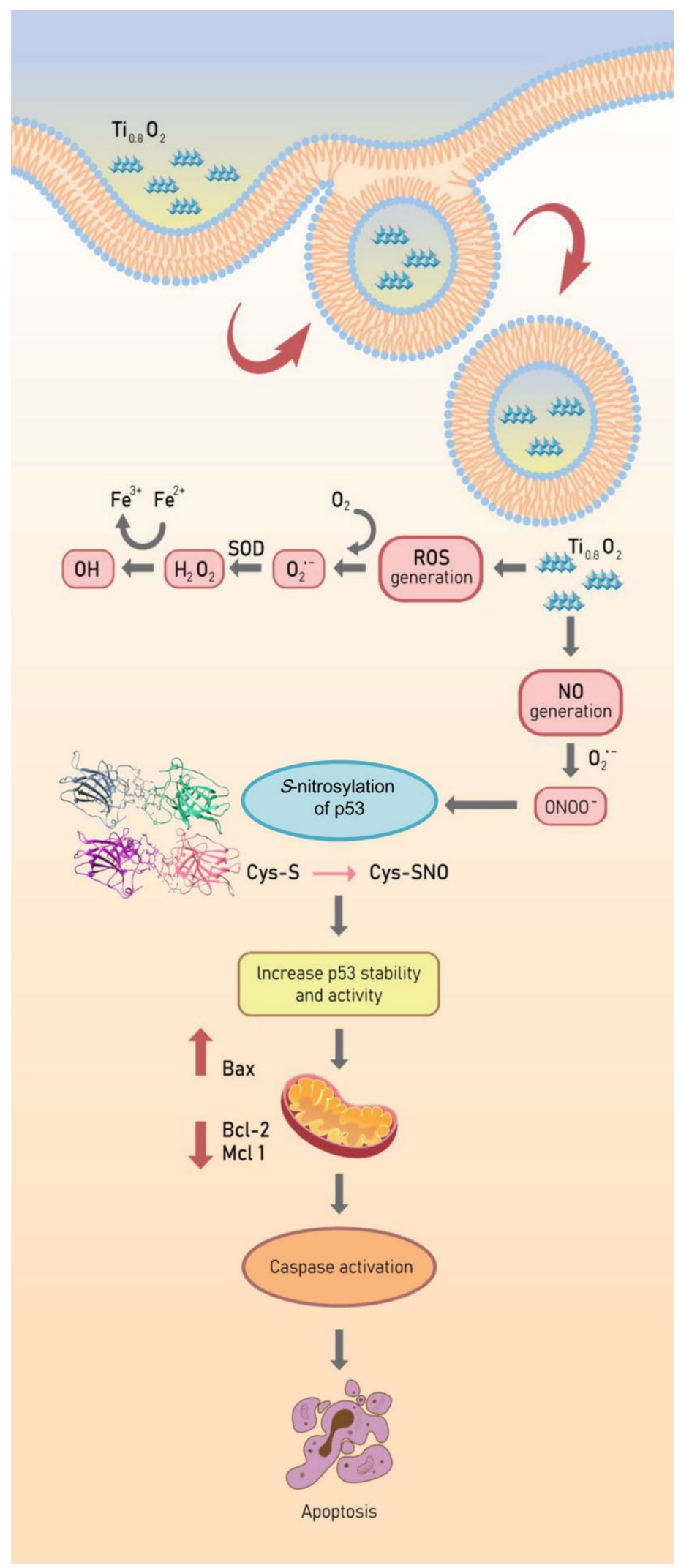

Figure 10. Schematic diagram of $\mathrm{Ti}_{0.8} \mathrm{O}_{2}$ nanosheet-mediated peroxynitrite generation that was associated with apoptosis via p53 upregulation in non-small cell lung cancer. 


\section{Conclusions}

In conclusion, our present study, for the first time, provides information on the effect of $\mathrm{Ti}_{0.8} \mathrm{O}_{2}$ nanosheet-induced apoptosis through a molecular mechanism involving peroxynitrite generation. After treatment with $\mathrm{Ti}_{0.8} \mathrm{O}_{2}$ nanosheets, it may directly control p53 by $S$-nitrosylation to stabilize the tetrameric structure of this protein. This reflects that the $S$-nitrosylation at $\mathrm{C} 182$ of p53 results in higher stability of the tetrameric protein-protein complex compared to the native p53. Therefore, the results of this study ingeminate the novel mechanism of action of nanomaterials for cancer therapy.

Author Contributions: Conceptualization, P.C.; supervision, P.C.; methodology, R.S., B.N., T.R., C.V., T.M. and P.C.; formal analysis, R.S., B.N. and P.C.; investigation, R.S., S.T., B.N., T.M. and P.C.; resources, P.C.; data curation, R.S., S.T. and P.C.; writing—original draft preparation, R.S., S.T. and P.C.; writing - review and editing, P.C.; funding acquisition, P.C. All authors have read and agreed to the published version of the manuscript.

Funding: The research was supported by research grant for talented mid-career researchers (TMRs) from the National Research Council of Thailand (NRCT), Thailand (STF6400601) and the Thailand Research Fund through the Royal Golden Jubilee Ph.D. program (Grant No. PHD/0135/2559).

Institutional Review Board Statement: The study was performed according to the guidelines of the Declaration of Helsinki and approved by the Ethics Committee of the Faculty of Medicine, Chulalongkorn University, Bangkok, Thailand (IRB 365/62).

Informed Consent Statement: Informed consent was obtained from all subjects involved in the study.

Data Availability Statement: Data are contained within the article.

Acknowledgments: The authors sincerely thank the Cell-Based Drug and Health Products Development Research Unit, Chulalongkorn University, for their support of this study.

Conflicts of Interest: The authors declare no conflict of interest.

\section{References}

1. Herbst, R.S.; Morgensztern, D.; Boshoff, C. The biology and management of non-small cell lung cancer. Nature 2018, 553, 446-454. [CrossRef]

2. Chen, J. The Cell-Cycle Arrest and Apoptotic Functions of p53 in Tumor Initiation and Progression. Cold Spring Harb. Perspect. Med. 2016, 6, 261-275. [CrossRef]

3. Dai, C.; Gu, W. p53 post-translational modification: Deregulated in tumorigenesis. Trends Mol. Med. 2010, 16, 528-536. [CrossRef] [PubMed]

4. Meek, D.W.; Anderson, C.W. Posttranslational modification of p53: Cooperative integrators of function. Cold Spring Harb. Perspect. Biol. 2009, 1, 950-962. [CrossRef]

5. Zhang, J.; Huang, K.; O'Neill, K.L.; Pang, X.; Luo, X. Bax/Bak activation in the absence of Bid, Bim, Puma, and p53. Cell Death Dis. 2016, 7, 226-234. [CrossRef]

6. Tang, D.; Kang, R.; Berghe, T.V.; Vandenabeele, P.; Kroemer, G. The molecular machinery of regulated cell death. Cell Res. 2019, 29, 347-364. [CrossRef]

7. Chène, $\mathrm{P}$. The role of tetramerization in p53 function. Oncogene 2001, 20, 2611-2617. [CrossRef]

8. Hainaut, P.; Milner, J. Redox modulation of p53 conformation and sequence-specific DNA binding in vitro. Cancer Res. 1993, 53, 4469-4473.

9. Buzek, J.; Latonen, L.; Kurki, S.; Peltonen, K.; Laiho, M. Redox state of tumor suppressor p53 regulates its sequence-specific DNA binding in DNA-damaged cells by cysteine 277. Nucleic Acids Res. 2002, 30, 2340-2348. [CrossRef] [PubMed]

10. Scotcher, J.; Clarke, D.J.; Mackay, C.L.; Hupp, T.; Sadler, P.J.; Langridge-Smith, P.R.R. Redox regulation of tumour suppressor protein p53: Identification of the sites of hydrogen peroxide oxidation and glutathionylation. Chem. Sci. 2013, 4, 1257-1269. [CrossRef]

11. Kim, D.H.; Kundu, J.K.; Surh, Y.J. Redox modulation of p53: Mechanisms and functional significance. Mol. Carcinog. 2011, 50, 222-234. [CrossRef] [PubMed]

12. Maillet, A.; Pervaiz, S. Redox Regulation of p53, Redox Effectors Regulated by p53: A Subtle Balance. Antioxid. Redox Signal. 2012, 16, 1285-1294. [CrossRef]

13. Wilson, G.; Garthwaite, J. Nitric Oxide. In Encyclopedia of Neuroscience; Academic Press Oxford: Oxford, UK, 2009; Volume 10, pp. 1151-1156.

14. Mengel, A.; Chaki, M.; Shekariesfahlan, A.; Lindermayr, C. Effect of nitric oxide on gene transcription -S-nitrosylation of nuclear proteins. Front. Plant Sci. 2013, 4, 293. [CrossRef] 
15. Hess, D.T.; Matsumoto, A.; Kim, S.O.; Marshall, H.E.; Stamler, J.S. Protein S-nitrosylation: Purview and parameters. Nat. Rev. Mol. Cell Biol. 2005, 6, 150-166. [CrossRef]

16. Radi, R. Oxygen radicals, nitric oxide, and peroxynitrite: Redox pathways in molecular medicine. Proc. Natl. Acad. Sci. USA 2018, 115, 5839. [CrossRef]

17. Pacher, P.; Beckman, J.S.; Liaudet, L. Nitric oxide and peroxynitrite in health and disease. Physiol. Rev. 2007, 87, 315-424. [CrossRef] [PubMed]

18. Boulaiz, H.; Alvarez, P.J.; Ramirez, A.; Marchal, J.A.; Prados, J.; Rodriguze-Serrano, F.; Perán, M.; Melguizo, C.; Aranega, A. Nanomedicine: Application areas and development prospects. Int. J. Mol. Sci. 2011, 12, 3303-3321. [CrossRef]

19. Zhang, W.; Yu, J.; Chang, H. Two dimensional nanosheets as conductive, flexible elements in biomaterials. J. Mater. Chem. B 2015, 3, 4959-4964. [CrossRef]

20. Petpiroon, N.; Bhummaphan, N.; Soonnarong, R.; Chantarawong, W.; Maluangnont, T.; Pongrakhananon, V.; Chanvorachote, P. $\mathrm{Ti}_{0.8} \mathrm{O}_{2}$ Nanosheets Inhibit Lung Cancer Stem Cells by Inducing Production of Superoxide Anion. Mol. Pharmacol. 2019, 95, 418-432. [CrossRef]

21. Sriphan, S.; Charoonsuk, T.; Maluangnont, T.; Vittayakorn, N. High-performance hybridized composited-based piezoelectric and triboelectric nanogenerators based on BaTiO3/PDMS composite film modified with $\mathrm{Ti}_{0.8} \mathrm{O}_{2}$ nanosheets and silver nanopowders cofillers. ACS Appl. Energy Mater. 2019, 2, 3840-3850. [CrossRef]

22. Cho, Y.; Gorina, S.; Jeffrey, P.D.; Pavletich, N.P. Crystal structure of a p53 tumor suppressor-DNA complex: Understandin tumorigenic mutations. Science 1994, 265, 346-355. [CrossRef] [PubMed]

23. Anandakrishnan, R.; Aguilar, B.; Onufriev, A.V. H++ 3.0: Automating pK prediction and the preparation of biomolecular structures for atomistic molecular modeling and simulations. Nucleic Acids Res. 2012, 40, 537-541. [CrossRef]

24. Nutho, B.; Rungrotmongkol, T. Binding recognition of substrates in NS2B/NS3 serine protease of Zika virus revealed by molecular dynamics simulations. J. Mol. Graph. Model. 2019, 92, 227-235. [CrossRef] [PubMed]

25. Meeprasert, A.; Hannongbua, S.; Kungwan, N.; Rungrotmongkol, T. Effect of D168V mutation in NS3/4A HCV protease on susceptibilities of faldaprevir and danoprevir. Mol. Biosyst. 2016, 12, 3666-3673. [CrossRef]

26. Boonma, T.; Nutho, B.; Rungrotmongkol, T.; Nunthaboot, N. Understanding of the drug resistance mechanism of hepatitis C virus NS3/4A to paritaprevir due to D168N/Y mutations: A molecular dynamics simulation perspective. Comput. Biol. Chem. 2019, 83, 107154. [CrossRef] [PubMed]

27. Maier, J.A.; Martinez, C.; Kasavajhala, K.; Wickstrom, L.; Hauser, K.E.; Simmerling, C. ff14SB: Improving the Accuracy of Protein Side Chain and Backbone Parameters from ff99SB. J. Chem. Theory Comput. 2015, 11, 3696-3713. [CrossRef] [PubMed]

28. Ryckaert, J.P.; Ciccotti, G.; Berendsen, H.J.C. Numerical integration of the cartesian equations of motion of a system with constraints: Molecular dynamics of n-alkanes. J. Comput. Phys. 1977, 23, 327-341. [CrossRef]

29. Darden, T.; York, D.; Pedersen, L. Particle mesh Ewald: An N·log(N) method for Ewald sums in large systems. J. Chem. Phys. 1993, 98, 10089-10092. [CrossRef]

30. Roe, D.R.; Cheatham, T.E. PTRAJ and CPPTRAJ: Software for processing and analysis of molecular dynamics trajectory data. J. Chem. Theory Comput. 2013, 9, 3084-3095. [CrossRef]

31. Miller Iii, B.R.; McGee, T.D.; Swails, J.M.; Homeyer, N.; Gohlke, H.; Roitberg, A.E. MMPBSA.py: An efficient program for end-state free energy calculations. J. Chem. Theory Comput. 2012, 8, 3314-3321. [CrossRef]

32. Shafagh, M.; Rahmani, F.; Delirezh, N. CuO nanoparticles induce cytotoxicity and apoptosis in human K562 cancer cell line via mitochondrial pathway, through reactive oxygen species and P53. Iran J. Basic Med. Sci. 2015, 18, 993-1000. [PubMed]

33. Kim, Y.M.; Bombeck Christopher, A.; Billiar Timothy, R. Nitric Oxide as a Bifunctional Regulator of Apoptosis. Circ. Res. 1999, 84, 253-256. [CrossRef]

34. Vousden, K.H.; Prives, C. Blinded by the Light: The Growing Complexity of p53. Cell 2009, 137, 413-431. [CrossRef]

35. Hollstein, M.; Sidransky, D.; Vogelstein, B.; Harris, C.C. p53 mutations in human cancers. Science 1991, 253, 49-53. [CrossRef]

36. Hainaut, P.; Hollstein, M. p53 and human cancer: The first ten thousand mutations. Adv. Cancer Res. 2000, 77, 81-137.

37. Kao, S.H.; Wang, W.L.; Chen, C.Y.; Chang, Y.L.; Wu, Y.Y.; Wang, Y.T.; Wang, S.P.; Nesvizhskii, A.I.; Chen, Y.J.; Hong, T.M.; et al. Analysis of Protein Stability by the Cycloheximide Chase Assay. Bio Protoc. 2015, 5, 137-144. [CrossRef]

38. Schonhoff, C.M.; Daou, M.C.; Jones, S.N.; Schiffer, C.A.; Ross, A.H. Nitric Oxide-Mediated Inhibition of Hdm2-p53 Binding. Biochemistry 2002, 41, 13570-13574. [CrossRef]

39. Quader, S.; Kataoka, K. Nanomaterial-Enabled Cancer Therapy. Mol. Ther. 2017, 25, 1501-1513. [CrossRef] [PubMed]

40. Patra, J.K.; Das, G.; Fraceto, L.F.; Campos, E.V.R.; del Pilar Rodriguez-Torres, M.; Acosta-Torres, L.S.; Diaz-Torres, L.A.; Grillo, R.; Swamy, M.K.; Sharma, S.; et al. Nano based drug delivery systems: Recent developments and future prospects. J. Nanobiotechnol. 2018, 16, 71. [CrossRef]

41. Kulkarni, M.; Mazare, A.; Gongadze, E.; Perutkova, Š.; Kralj-Iglič, V.; Milošev, I.; Schmuki, P.; Iglič, A.; Mozetič, M. Titanium nanostructures for biomedical applications. Nanotechnology 2015, 26, 62002. [CrossRef] [PubMed]

42. Wu, S.; Weng, Z.; Liu, X.; Yeung, K.; Chu, P. Functionalized TiO2 Based Nanomaterials for Biomedical Applications. Adv. Funct. Mater. 2014, 24, 5464-5481. [CrossRef]

43. Arunachalam, K.; Sankar, R.; Anusha, C.; Saravanan, K.; Aarthy, K.; Karthic, S.; Mathuram, T.I.; Ravikumar, V. Copper oxide nanoparticles induce anticancer activity in A549 lung cancer cells by inhibition of histone deacetylase. Biotechnol. Lett. 2018, 40, 249-256. 
44. Ma, S.; Miao, H.; Luo, Y.; Sun, Y.; Tian, X.; Wang, F.; You, C.; Peng, S.; Tang, G.; Yang, C.; et al. FePt/GO Nanosheets Suppress Proliferation, Enhance Radiosensitization and Induce Autophagy of Human Non-Small Cell Lung Cancer Cells. Int. J. Biol. Sci. 2019, 15, 999-1009. [CrossRef]

45. Satapathy, S.R.; Mohapatra, P.; Preet, R.; Das, D.; Sarkar, B.; Choudhuri, T.; Wyatt, M.D.; Kundu, C.N. Silver-based nanoparticles induce apoptosis in human colon cancer cells mediated through p53. Nanomed. J. 2013, 8, 1307-1322. [CrossRef] [PubMed]

46. Haupt, S.; Haupt, Y. Importance of p53 for cancer onset and therapy. Anti Cancer Drugs 2006, 17, 725-732. [CrossRef] [PubMed]

47. Hsin, Y.H.; Chen, C.F.; Huang, S.; Shih, T.S.; Lai, P.S.; Chueh, P. The apoptotic effect of nanosilver is mediated by a ROS-and JNK-dependent mechanism involving the mitochondrial pathway in NIH3T3 cells. Toxicol. Lett. 2008, 179, 130-139. [CrossRef]

48. Loaiza-Pérez, A.I.; Kenney, S.; Boswell, J.; Hollingshead, M.; Alley, M.C.; Hose, C.; Ciolino, H.P.; Yeh, G.C.; Trepel, J.B.; Vistica, D.T.; et al. Aryl hydrocarbon receptor activation of an antitumor aminoflavone: Basis of selective toxicity for MCF-7 breast tumor cells. Mol. Cancer Ther. 2004, 3, 715-725.

49. McLean, L.; Soto, U.; Agama, K.; Francis, J.; Jimenez, R.; Pommier, Y.; Sowers, L.; Brantley, E. Aminoflavone induces oxidative DNA damage and reactive oxidative species-mediated apoptosis in breast cancer cells. Int. J. Cancer 2008, 122, 1665-1674. [CrossRef]

50. Islam, B.U.; Habib, S.; Ahmad, P.; Allarakha, S.; Moinuddin, A.A. Pathophysiological Role of Peroxynitrite Induced DNA Damage in Human Diseases: A Special Focus on Poly (ADP-ribose) Polymerase (PARP). Indian J. Clin. Biochem. 2015, 30, 368-385. [CrossRef]

51. Cobbs, C.S.; Samanta, M.; Harkins, L.E.; Gillespie, G.Y.; Merrick, B.A.; MacMillan-Crow, L.A. Evidence for peroxynitrite-mediated modifications to 553 in human gliomas: Possible functional consequences. Arch. Biochem. Biophys. 2001, 394, 167-172. [CrossRef]

52. Pryor, W.A.; Squadrito, G. The chemistry of peroxynitrite: A product from the reaction of nitric oxide with superoxide. Am. J. Physiol. 1995, 268, 699-722. [CrossRef]

53. Chao, C.; Saito, S.; Kang, J.; Anderson, C.W.; Appella, E.; Xu, Y. p53 transcriptional activity is essential for p53-dependent apoptosis following DNA damage. EMBO J. 2000, 19, 4967-4975. [CrossRef]

54. Sun, J.; Steenbergen, C.; Murphy, E. S-nitrosylation: NO-related redox signaling to protect against oxidative stress. Antioxid. Redox Signal. 2006, 8, 1693-1705. [CrossRef] [PubMed]

55. Stamler, J.S.; Hess, D.T. Nascent nitrosylases. Nat. Cell Biol. 2010, 12, 1024-1026. [CrossRef] [PubMed]

56. Nakamura, T.; Tu, S.; Akhtar, M.W.; Sunico, C.R.; Okamoto, S.I.; Lipton, S.A. Aberrant protein s-nitrosylation in neurodegenerative diseases. Neuron 2013, 78, 596-614. [CrossRef]

57. Imamura, K.; Ogura, T.; Kishimoto, A.; Kaminishi, M.; Esumi, H. Cell cycle regulation via p53 phosphorylation by a $5^{\prime}-$ AMP activated protein kinase activator, 5-aminoimidazole- 4-carboxamide-1-beta-D-ribofuranoside, in a human hepatocellular carcinoma cell line. Biochem. Biophys. Res. Commun. 2001, 287, 562-567. [CrossRef]

58. Levine, A.J. p53, the cellular gatekeeper for growth and division. Cell 1997, 88, 323-331. [CrossRef]

59. Joerger, A.C.; Fersht, A.R. Structure-function-rescue: The diverse nature of common p53 cancer mutants. Oncogene 2007, 26, 2226-2242. [CrossRef] [PubMed]

60. Jovanka, G.A.; Guilermina, L. p53 tetramerization: At the center of the dominant-negative effect of mutant p53. Genes Dev. 2020, 34, 1128-1146.

61. Takano, K.; Yamagata, Y.; Funahashi, J.; Hioki, Y.; Kuramitsu, S.; Yutani, K. Contribution of intra- and intermolecular hydrogen bonds to the conformational stability of human lysozym. Biochemistry 1999, 38, 12698-12708. [CrossRef]

62. Yamagata, Y.; Kubota, M.; Sumikawa, Y.; Funahashi, J.; Takano, K.; Fujii, S.; Yutani, K. Contribution of hydrogen bonds to the conformational stability of human lysozyme: Calorimetry and X-ray analysis of six tyrosine $\rightarrow$ phenylalanine mutants. Biochemistry 1998, 37, 9355-9362. [CrossRef] [PubMed]

63. Brown, G.C.; Borutaite, V. Nitric oxide, cytochrome c and mitochondria. Biochem. Soc. Symp. 1999, 66, 17-25. [CrossRef] [PubMed] 